\title{
Note
}

\section{Plants, Poverty, and Pharmaceutical Patents}

\author{
Shayana Kadidal
}

Cancers like Hodgkin's disease and pediatric lymphocytic leukemia once killed the majority of their young victims. Today's survivors owe their lives to the luck of two scientists who accidently discovered the wonder drugs vinblastine and vincristine while they were investigating Madagascar's wild rosy periwinkle for other medical properties. ${ }^{1}$ Since their introduction in the early 1960's, these spectacular examples of plant-derived pharmaceuticals have been primarily responsible for improving Hodgkin's disease remission rates from $19 \%$ to $80 \%$ and pediatric leukemia survival rates to a once unimaginable $90 \% .^{2}$ The pharmaceutical literature is filled with similar examples. ${ }^{3}$ Compared with the alternative, purely synthetic routes, the use of biological sources is often both cheaper and more likely to produce breakthroughs in the highly saturated drug market. ${ }^{4}$

1. Sam Thernstrom, Bio-diversity, GAZETTE (Montreal), Apr. 10, 1993, at B6.

2. Diane Jukofsky, Medicinal Plant Research Leads Scientists to Rain Forests, DRUG Topics, Apr. 22,1991 , at 26.

3. A "time honored route used since the beginning of pharmacology is to collect a botanical, animal or microbial source of a possible therapeutic agent and to extract and then purify the active pharmacological agent. Morphine (1806) quinine (1823), atropine (1833) and digitalis, are early examples ... of plant derived medicinals." BARRIE G. JAMES, THE FUTURE OF THE MULTINATIONAL PHARMACEUTICAL INDUSTRY To 1990, at 61 (1977). The use of biological sources began to decline in the 1950's, however. Because few species had been subject to any kind of systematic assay as of the late 1970's, the field still has untapped potential. $I d$. at 61 . A common assaying methodology "is to screen traditional herbal medicines for unexploited natural products." EDWARD YOXEN, THE GENE BUSINESS: WHO SHOULD CONTROL BIOTECHNOLOGY? 11 (1983).

4. New pharmaceutical research employs a variety of methodologies. One method is to synthesize totally new structures more or less randomly and then to test them clinically for biological effects; the highly technical lab work and clinical work makes this the most expensive investigatory route. A second, 
Unfortunately, this pharmaceutical success story has a darker side. Eli Lilly, the corporate producer of vinblastine and vincristine, earns roughly $\$ 100$ million dollars each year from these drugs ${ }^{5}$ - while Madagascar, the original home of the plants in which these drugs were found, earns nothing from them. ${ }^{6}$ As early as 1982 , an estimated $50 \%$ of the prescriptions filled in the United States were for pharmaceuticals derived in some way from naturally occurring compounds, accounting for sales estimated at $\$ 20$ billion in the United States alone. ${ }^{7}$ Yet little or none of this goes to the countries where these naturally occurring compounds were originally found. The inequity of allowing multinational corporations to monopolize the profits from the exploitation of the natural resources of less developed countries (LDC's) ${ }^{8}$-the diverse biological and biochemical legacy of the many species found or preserved only in their wild forests or in their farmers' cultivated fields-has until recently attracted little more than theoretical interest. However, as

more fruitful, and less expensive method bases new products on a known metabolite's structure. Even cheaper processes skip the synthetic steps altogether. One such method is to test existing drugs for useful new side effects; minoxidil, for example, was used as a vasodilator for cardiac patients before researchers discovered its more profitable use as a treatment for baldness. The final method, which is the subject of this Note, is to test naturally occurring biological substances for beneficial medical effects. See supra note 3. Such testing can be random, or it can be based on ethnopharmacological leads, i.e., information about traditional medicinal uses of plants. Naturally occurring drugs can usually be synthesized after enough of a sample has been obtained to isolate the active chemical ingredient and determine its structure. Synthesis is often a cheaper way to produce a drug in bulk than natural extraction, and also ends dependence on a supply of the source plant.

Typically 1 in 5000 tested compounds eventually reaches the market after overcoming hurdles such as efficacy tests, safety tests, and market redundancy. The more hit-or-miss form of testing, usually with existing or synthetically modified ("semi-synthetic") compounds, was more common in the United States before the 1970's. The 1962 Kefauver-Harris amendments, adding the requirement of efficacy to that of safety for FDA approval, caused researchers to target "chronic ailments without cures," because cures for these diseases could more easily be shown to be efficacious and, if they aimed at stopping these ailments in the early stages, less likely to produce side effects. SURESH B. PRADHAN, INTERNATIONAL PHARMACEUTICAL MARKETING 41-42 (1983). Exploring natural sources generally produces more such breakthroughs than modifying existing products.

5. Jukofsky, supra note 2, at 26; see also Norman Myers, Draining the Gene Pool: The Causes, Course and Consequences of Genetic Erosion, in SEEDS AND SOVEREIGNTY 90, 96 (Jack R. Kloppenburg, Jr. ed., 1988) (stating annual sales of all drugs derived from rosy periwinkle at $\$ 160$ million).

6. Pharmaceutical Companies Go "Chemical Prospecting" for New Medicines, PHARMaceutical Bus. NEWS, Aug. 21, 1992, available in LEXIS, Nexis Library, PBNWS File.

7. NORMAN MYERS, A WeAlTH OF WILD SPECIES 90 (1983) (citing unpublished 1982 study by Norman Farnsworth); see also Richard E. Shultes, The Future of Plants as Sources of New Biodynamic Compounds, in PlanTs in THE DEVELOPMENT of MODERN MEDICINE 103, 105 (Tony Swain ed., 1972) (stating that in $196750 \%$ of all U.S. prescriptions were for drugs whose principal agents were naturally derived, from higher plants $(25 \%)$, from microbes (12\%), from animals $(6 \%)$, or from minerals $(7 \%)$; the other $50 \%$ were synthetically produced).

8. Most of the "Vavilov centers of genetic diversity" are indeed "situated predominantly in what is now known as the Third World." These eight regions, identified first in the 1920's by the Soviet botanist N.I. Vavilov, are defined as "centers of origin of most of the world's economically important crops." Although the U.S. Midwestern, European Mediterranean, and the Euro-Siberian agricultural regions are listed among the 12 current sites of such diversity (Zhukovsky gene megacenters), the crops composing the diversity of these regions were mostly imported from other regions. Of Vavilov's eight original centers of origin, only the Mediterranean is not currently underdeveloped. JACK R. KLOPPENBURG, JR., FIRST THE SEED: THE POLITICAL ECONOMY OF PLANT BIOTECHNOLOGY, 1492-2000, at 46 (1988); Jack R. Kloppenburg, Jr. \& Daniel L. Kleinman, Seeds of Controversy: National Property Versus National Heritage, in SEEDS AND SOVEREIGNTY, supra note 5, at 173, 175-81. 
political consciousness concerning environmental issues has grown throughout the world, LDC's have increasingly demanded some sort of equitable compensation, often in the form of intellectual property rights, for their farmers' preservation efforts and for national policies that forgo more destructive forms of development, such as large-scale heavy industrialization or clear-cut agriculture. ${ }^{9}$ Remarkably, Western pharmaceutical companies, spurred on by the high cost and high risk of synthetic routes of drug production, by the promise of these "biodiversity" sources, ${ }^{10}$ and by the fear of squandering resources, have sometimes cooperated with these demands. ${ }^{11}$ A critical drawback to the pharmaceutical use of biodiversity sources is that the patent system has traditionally refused to protect compounds that already exist in nature.

This combination of factors has led 167 nations, including the United States, ${ }^{12}$ to sign the Convention on Biological Diversity ${ }^{13}$ (Rio Convention), opened for signature at the 1992 Earth Summit in Rio de Janeiro. This Note argues that the Rio Convention requires that less developed countries receive intellectual property rights in pharmaceutically useful chemicals that are derived from their biodiversity resources ${ }^{14}$ and that a system of such rights would provide a more equitable and more efficient method of valuing these resources than any that can be achieved without such rights. ${ }^{15}$ Unfortunately, effective intellectual property rights in biodiversity resources cannot be created simply by abolishing the traditional exclusion of natural products from patentability: pharmaceutical companies have already devised methods to circumvent the natural products exception, and these methods would also allow

9. Madagascar, an isolated evolutionary haven much like Australia, possesses "one of the most distinctive floras and faunas in the world [but] has already lost 93\% of its forest cover." E.O. Wilson, The Current State of Biological Diversity, in BIODIVERSTTY 3, 10 (E.O. Wilson ed., 1988).

10. The pharmaceutical industry's spokespersons seemed to acknowledge that the industry was experiencing a trough in innovation which started in the 1960's and deepened in the 1970's. From 1961 to 1973 the number of new drugs introduced onto the market dropped by a third, a phenomenon attributable only in part to the Kefauver amendment. Daniel Chudnovsky, Patents and Trademarks in Pharmaceuticals, in PHARMaceuticals AND HEALTH IN THE THIRD World 187, 188 (Surendra J. Patel ed., 1983). In 1974 FDA Commissioner Alexander Schmidt announced "we have temporarily exhausted the exploitations of known concepts and tools." JAMES, supra note 3, at 74 (quoting Schmidt).

11. U.S. Biotech Companies Leery of Biodiversity Treaty, STAR TRIB., June 11, 1992, at 13A (describing Genentech's statement opposing Rio Convention and contrary position taken by many other pharmaceutical concerns). The article reports that many best-selling patents are scheduled to expire soon, leaving pharmaceutical companies "peering southward." Id.; see also Julie Rovner, Rise in Prices of Prescription Drugs Threatens Many, STAR TRIB., Aug. 10, 1992, at 4A (reporting that patents expired on drugs with annual sales of $\$ 1.9$ billion in 1992 and $\$ 2.6$ billion in 1993, up from $\$ 363$ million in 1991).

12. William K. Stephens, Gore Promises U.S. Leadership on Sustainable Development Path, N.Y. TIMES, June 15, 1993, at C4. The U.S. signed the Convention on June 4,1993, the last day it remained open for signature. As It Signs Treaty, United States Calls for Global Patent Protection for Biotech, INT'L ENV'T DAILY (BNA) (June 8, 1993).

13. Convention on Biological Diversity of the United Nations Conference on Environment and Development, opened for signature June 5, 1992, 31 I.L.M. 818 [hereinafter Rio Convention].

14. See infra Part I.

15. See infra Part II. 
them to circumvent biodiversity patents held by LDC's. ${ }^{16}$ Moreover, existing doctrines of equitable patent scope expansion may be inadequate to protect the proposed biodiversity patent rights. Fundamental modifications in our system of chemical patents may therefore be required in order to fulfill the aspirations of the Rio Convention. ${ }^{17}$ In any event, future patent infringement determinations must be informed by characteristics beyond mere literal chemical structure, and such determinations should be shifted to the Patent Office. While the changes proposed here are extensive, they have the potential to make pharmaceutical development more efficient and responsive to diverse worldwide needs as well as to encourage the conservation of our priceless biological inheritance.

\section{THE RIO CONVENTION}

\section{A. The Text of the Treaty: "impressively opaque" ?"}

Like many modern multilateral treaties, the Rio Convention makes clear its goals but not the means to implement them. ${ }^{19}$ Its aspirational values are clear enough: the Preamble emphasizes the value of the conservation of biological resources ${ }^{20}$ as well as the need to share fairly the profits arising from these resources. ${ }^{21}$ The Convention therefore seeks

the conservation of biological diversity, the sustainable use of its components and the fair and equitable sharing of the benefits arising out of the utilization of genetic resources, including by appropriate access to genetic resources and by appropriate transfer of relevant technologies, taking into account all rights over those resources and to technologies, and by appropriate funding. ${ }^{22}$

The Convention becomes more specific-and more worrisome to the giant pharmaceutical concerns that lobbied against its ratification-in Article 15, which recognizes states' sovereign rights over their natural resources, including

16. See infra Part III.

17. See infra Part IV.

18. The Earth Conference: Biodivisive, ECONOMIST (U.S. Edition), June 13, 1992, at 93, 94.

19. Unfortunately, the gargantuan United Nations document designed to explain the various treaties approved at Rio-Agenda 21 -is equally vague. See AGENDA 21 \& THE UNCED PROCEEDINGS (Nicholas A. Robinson et al. eds., 1992). One reason for this obscurity is the remarkable haste with which the Convention was drafted. See Melinda Chandler, The Biadiversity Convention: Selected Issues of Interest to the International Lawyer, 4 COLO. J. INT'L. ENVTL. L. \& POL'Y 141, 143 (1993); The Earth Conference: Biodivisive, supra note 18, at 93.

20. Rio Convention, supra note 13 , at 822 .

21. Id. The Preamble also stresses the precautionary nature of conservation attempts: given the lack of knowledge concerning the potential value of these resources, the Convention errs on the side of conservation.

22. Id., art. 1, 31 I.L.M. at 823. 
"the authority to determine access to genetic resources."23 Article 15 requires signatories to take whatever measures are necessary to ensure that the results and benefits of research utilizing genetic resources are shared fairly with the nation of origin. ${ }^{24}$ Although Article 16 emphasizes the need to establish access to and transfer of genetic-resource technology among Western and LDC countries, ${ }^{25}$ it fails to propose a regime to assign the resulting intellectual property rights. ${ }^{26}$ Article 16 does acknowledge the continued existence of intellectual property rights in this technology. ${ }^{27}$

\section{B. The Convention in Context}

A worldwide system of patent rights in genetic resources would achieve the goals of the Rio Convention. A look at earlier attempts to create international schemes of intellectual property rights in natural resources provides a useful gloss on the Convention's terminology, and also illustrates why such patent rights must be provided if the Convention is to achieve its goals. Most conflicts over intellectual property rights in natural genetic resources have concerned varieties of food crops, rather than the relatively obscure area of pharmaceutically-valuable phytochemicals. ${ }^{28}$ Conflicts concerning food crops surfaced during the enactment of the United States Plant Varieties Protection Act of 1970 (PVPA) ${ }^{29}$ and came to a head over the United Nations Food and Agriculture Organization's International Undertaking on Plant Genetic Resources of 1983 (FAO Undertaking). ${ }^{30}$

The plant varieties protected by the PVPA do not include the products of traditional breeding efforts, which are not considered novel. Therefore, the PVPA favors Western agricultural breeders over LDC breeders. The PVPA allows commercial protection for any new species, even those that reproduce

23. Id., art. 15, $\$ 1,31$ I.L.M. at 828 .

24. Id., art. 15, § 7, 31 I.L.M. at 828 .

25. Genentech, Inc. and other biotechnology companies fear that Articles 15 and 16 would tum "technology transfer" and "equitable sharing" into compulsory licensing and intellectual property expropriation. Article 16 requires that developed nations ensure that their "private sector facilitates access to, joint development and transfer of technology ... for the benefit of both governmental institutions and the private sector of developing countries." Id., art. 16, \& 4,31 I.L.M. at 829. Biotechnology companies fear that this provision, together with the Convention's financing provisions, will allow developing countries to claim a portion of the proceeds from successful products retroactively, after the risky investment period of development has passed. Such claims would prevent the private sector from accurately predicting future returns from research projects that require enormous investments. U.S. Biotech Companies Leery of Biadiversity Treaty, supra note 11, at 13A.

26. Rio Convention, supra note 13, art. 16, § 1, 31 I.L.M. at 829.

27. Id., art. 16, § 3, 31 I.L.M. at 829 (emphasis added).

28. A phytochemical is any chemical derived from a plant source.

29. Pub. L. No. 91-577, 84 Stat. 1542 (1970) (codified at 7 U.S.C. $\S \S 2321-2583$ (1988)). Our PVPA actually followed the lead of 17 European nations in promoting "the commodification of the seed." See KLOPPENBURG, supra note 8, at 130, 136-37 (1988).

30. Report of the Conference of FAO, Food and Agriculture Organization of the United Nations, 22d Sess. II 285, U.N. Doc. C 83/REP (1983) (adopting International Undertaking on Plant Genetic Resources). 
sexually, ${ }^{31}$ whereas the older Plant Patent Act of 1930 provides patent protection only for asexually reproducing varieties. ${ }^{32}$ The usual subjects of plant patent protection are sterile hybrid lines, seed for which is produced by crossing two homogeneous sexually reproducing varieties at the seed manufacturer's facilities. The crop produced from such seed is generally sterile ${ }^{33}$ and thus already protected from illicit copying, so long as the trade secrecy of the parent lines is maintained. The PVPA extended legal protection to new varieties that had no natural protection from copying, while excluding known varieties.

The transnational seed companies have argued that their advanced lines deserve to receive intellectual property protection because Western breeding utilizes more highly technical labor and the resulting products are exclusively sold as commodities. ${ }^{34}$ Conversely, their position on expanding this protection to encompass raw germplasm, the genetic components of the great "natural" diversity present in (mainly) Third World crops, is that it should be considered the "common heritage of humankind," 35 the gift of nature to the present generation. Several arguments have been advanced to explain why these traditional breeders' lines should not be entitled to the same level of propertyright protection that the products of high-tech breeding receive. The most significant is the claim that a wild species (or its raw germplasm) is hard to value and thus hard to price, due to its indeterminate usefulness. Only after some experimentation, for example, would a breeder find out if genes for specific traits from a raw germplasm could be easily introduced into a successful line of its own that contained the bulk of desirable genes. A strict

31. 7 U.S.C. \$ 2402(a) (1988); see also STEVEN C. WITT, BIOTECHNOLOGY AND GENETIC DIVERSITY 84 (1985) (describing weaknesses in commercial protections offered by PVPA).

32. 35 U.S.C. $\$ \$ 161-164$ (1988). Note that after 1983, judicial interpretations of the Plant Patent Act have held that it does not preempt protection under utility patent legislation; breeders can now make use of either type of protection. See Ex parte Hibberd, 227 U.S.P.Q.2d (BNA) 443 (Bd. Pat. App. \& Int. 1985); KLOPPENBURG, supra note 8, at 263.

33. Crop lines with sterile seed might seem to have limited commercial use, but in fact, high-tech farmers often prefer the predictable features and yields produced by genetically homogeneous hybrid seed. The sterility of the resulting crop is counter-balanced by the benefits of uniformity. High-tech farmers often buy all their seed from a breeder, who benefits from this dependable market.

34. This commodification of the seed is a relatively new phenomenon:

[Seed trade] lobbying has successfully eliminated varietal performance as a requirement for certification. . . . The key word . . . is not "yield" or "quality" but "choice." As one company executive put it, the "seed industry is and always has been a merchandizing industry. After all, we are only a few years away from the time that we all had the same public varieties to sell." KLOPPENBURG, supra note 8 , at 143 (quoting D. Kinsell). There are parallels here to the incipient commodification by multinational drug companies of naturally occurring pharmaceuticals, which the patent system has often but not always left in the public domain. See infra text accompanying notes 85-103.

35. MYERS, supra note 7, at 24; see also Garrison Wilkes, Current Status of Crop Plant Germplasm, 1 CRITICAL REVS. PlanT SCI. 133, 156 (1983). The phrase "common heritage of mankind" first entered the international environmental law lexicon with Article 136 of the United Nations Convention on the Law of the Sea, done at Montego Bay, Dec. 10, 1982, 21 I.L.M. 1261, 1293, which declares the seabed and its resources the "common heritage of mankind." The Convention on the Law of the Sea also emphasizes the opposition between its "common heritage" approach and a system of "sovereignty or sovereign rights" over these resources. Id., art. 137, 21 I.L.M. at 1293. The former precludes the latter. 
regime of intellectual property protection might lead to the undervaluation and/or underutilization of raw germplasm sources for genetic traits. Another argument relies on the fact that Western commercial lines involve valuable input of technical labor, which should be rewarded with legal protection under a labor theory of property rights. By contrast, raw germplasm is only valuable after the introduction of technical labor allows incorporation of the genetic material into a new commercial line. ${ }^{36}$ This argument neglects the millennia of farmers' labor invested in quite effective traditional breeding practices.

Nonetheless, in 1983 most LDC's endorsed the FAO Undertaking and thereby accepted the idea that traditional breeders' lines should not receive the protection afforded to commercial breeders' lines. The Undertaking strove to produce a system of seed banks around the globe that would contain all of the land races ${ }^{37}$ of the underdeveloped world as well as the advanced lines of the industrialized agricultural world. These seed banks would be open to any breeder who needed to draw from them.

Minority voices in the underdeveloped and socialist worlds argued that they had little to gain from such an arrangement. They contended that the Undertaking offered a vast storehouse of diverse genetic material from the underdeveloped "South" in exchange for genetically narrow lines of greater technological sophistication but dubious utility from the industrialized "North." The advanced nations would therefore lose little in the Undertaking bargain, because recognizing all lines as the "common genetic heritage of mankind" would still leave them in a better financial and scientific position to take advantage of a now larger and more easily accessed gene pool. This arrangement would, in fact, cater more to the West's commercial stake in maintaining diversity ${ }^{38}$ than to the LDC's pressing need to raise capital for the production of agricultural technology suited to their needs. ${ }^{39}$

36. On these arguments generally, see Kloppenburg \& Kleinman, supra note 8 , at 188-92, and KLOPPENBURG, supra note 8, at 184-89. Another argument claims that no "resource degradation" occurs with germplasm exploitation, as it would with depletable natural resources, since one seed contains the entire genetic code of a native strain in a useful (reproducible) form. But this proposition is equally true of all forms of intellectual property. See, e.g., Roger A. Sedjo, Property Rights and the Protection of Plant Genetic Resources, in SEEDS AND SOVEREIGNTY, supra note 5, at 293, 303-04.

37. In the literature on biological diversity, the term "land races" is used to refer to actively cultivated crop varieties that have been developed in traditional agricultural systems through both natural and human selection. WITT, supra note 31 , at 23.

38. Genetically, Western crops tend to be very homogenous. This lack of genetic diversity deprives them of collective resistance to epidemiological disasters like the Irish potato famine of the mid-nineteenth century, the U.S. wheat stem rust epidemic of 1954, and the Southern com leaf blight of 1970. See H. Garrison Wilkes, Plant Genetic Resources Over Ten Thousand Years: From a Handful of Seed to the CropSpecific Mega-Gene Banks, in SEEDS AND SOVEREIGNTY, supra note 5, at 67, 73-75. Such disasters illustrate the wisdom behind the ubiquitous slogan of biodiversity conservationists: "To keep every cog and wheel is the first precaution of intelligent tinkering." Aldo Leopold, The Round River, in A SAND COUNTY ALMANAC 175, 177 (enlarged ed. 1966).

39. Continued dependence on the North's agribusiness to produce this technology would only deepen the South's technological dependence on the North, facilitate further devaluation of genetic factors with the creation of a one-way market, and reinforce the already divisive social differentiation among peasant producers. 
A number of academic sociologists ${ }^{40}$ and a decided minority of LDC specialists ${ }^{41}$ have argued that a system of national sovereignty in genetic resources would better suit the needs of Third World agriculture. Such a system would take the form of intellectual property rights held by the governments of the LDC's in the name of the generations of farmer-breeders responsible for their diversity and continued existence. National elites in the LDC's might still reap the direct gains from such a system of property rights, but even these gains could lead to long-term societal benefits, according to dependency-theory models, by facilitating the development of basic scientific research in LDC's geared towards their specific agricultural needs. ${ }^{42}$ This system would allow effective protection of hybrid strains, which would be impossible under the Undertaking without special exemptions. ${ }^{43}$ Given the differences in the agricultural systems of the North and the South, a regime of natural-resource rights might result mostly in payments between LDC's, rather than from developed countries to LDC's, but the development of basic science in the LDC's is a crucial step in eliminating the wide qualitative gap between the agricultural systems of the North and the South. The FAO's 1983 position opposes any such system of national sovereignty in plant genetic resources. Its equivalent in the pharmaceutical field is the minimalist policy of refusing to recognize any patent rights in this area, a policy followed by many LDC's. ${ }^{44}$

Given that the signatories of the FAO Undertaking-the majority of them LDC's - rejected proposals concerning national sovereignty in plant breeders' rights in $1983,{ }^{45}$ one might wonder why patent rights should be the preferred protective remedy under the Rio Convention. The Convention's vague wording, standing alone, might lead us to believe that it should be interpreted according to the free-exchange policies encouraged by the Undertaking. ${ }^{46}$ According to

40. See, e.g., KLOPPENBURG, supra note 8, at 288.

41. Among the LDC contingent, only socialist Ethiopia voted against the Undertaking and, implicitly, for a system of state control over genetic resources. Various nations currently claim national sovereignty over certain crucial crops, including Brazil (over rubber varieties), Ecuador (cocoa), Ethiopia (coffee), Iraq (date palm), and Iran (wild pistachio). Charles F. Murphy, Institutional Responsibility of the National Plant Germplasm System, in SEEDS AND SOVEREIGNTY, supra note 5, at 204, 217 n.3.

42. See Daniel J. Goldstein, Biotechnology in Underdevelopment, 4 BIO/TECHNOLOGY 672 (1986). See generally Daniel J. Goldstein, Molecular Biology and the Protection of Germplasm: A Matter of National Security, in SEEDS AND SOVEREIGNTY, supra note 5, at 315.

43. Under the Undertaking, presumably even trade-secret parent lines should become accessible.

44. See, e.g., Note, Exclusions from Patent Protection, Memorandum of the International Bureau of WIPO, 27 INDUS. PROP. 192, 192-93 (1988).

45. Apparently, the position of many LDC's on plant breeders' rights has changed. See Rebecca L. Margulies, Protecting Biodiversity: Recognizing International Intellectual Property Rights in Plant Genetic Resources, 14 MiCH. J. INT'L L. 322, 344-45 (1993). Margulies argues that property rights in biodiversity resources are consistent with existing law on property rights in plant species.

46. Before the Undertaking, no United Nations agreements directly touched on the question of rights in germplasm/genetic resources. The one multilateral international agreement proposed in the intervening years, the ASEAN Agreement on the Conservation of Nature and Natural Resources, done at Kuala Lumpur, July 9, 1985, available in 15 ENVTL. POL'Y \& L. 64 (1985), was regional in scope; all the signatories were LDC's. It neither contained formal legal guidelines nor produced much formal legal activity, but instead called mainly for the generation of studies. For a summary of the ASEAN agreement 
this reading, the Convention promotes the selective transfer from the North of technologies covered by patents in those countries, in exchange for access to the genetic resources of the South. These contractual exchanges would be negotiated on a case-by-case basis. LDC governments would presumably negotiate with the appropriate transnational corporations for the initial release of the materials and would then leave subsequent protection in the hands of the corporations. $^{47}$

A reading of the Convention in light of the debate that surrounded and followed the Undertaking, however, produces a different interpretation. Nowhere in the Convention is the phrase "common heritage of mankind" used to describe biodiversity resources. Though the Preamble affirms "that the conservation of biological diversity is a common concern of humankind," the insertion of the term "concern" evokes duties accompanying rights, rather than a preference for free and open use. In fact, a general emphasis on rights throughout the text contradicts the assertion that the Convention is hostile to all constraints on the free exchange of germplasm. Rather, the Convention's repeated reference to the "sovereign rights of States over their natural resources" ${ }^{\text {"49 }}$ must be read as a reference to the language of the Undertaking minority and their academic supporters. The recent history of this phrase allows no other interpretation. Establishing "sovereign rights" over natural resources is the opposite of treating them as the "common heritage" of humanity. ${ }^{50}$ The language of "sovereign rights" was so strongly associated with the program of the Undertaking minority that its use by the drafters of the Rio Convention can only be understood as endorsing a system of national intellectual property rights in biodiversity resources.

\section{ECONOMIC JUSTIFICATIONS FOR PATENT RIGHTS IN BIODIVERSITY RESOURCES}

Beyond the intent of its drafters, several policy considerations indicate that the Rio Convention should be construed to require a system of patent rights

and subsequent action, see 2 AGENDA 21 \& THE UNCED PROCEEDINGS, supra note 19, at 1162-64.

47. A U.S. State Department official was quoted as saying that he expected that now, under Rio, "access [to genetic resources] is open, but not necessarily free," and "could be on the basis of commercial contract." Biodiversity: A Progress Report on the Convention and the Strategy, Global ENVTL. Change REP., Aug. 16, 1992, available in LEXIS, ENVIRN Library, ZEV1 File.

48. Rio Convention, supra note 13, pmbl., II 4, 31 I.L.M. at 822.

49. Rio Convention, supra note 13, pmbl., II 5; art. 15, § 1; art. 3, 31 I.L.M. at 822, 828, 824. This terminology was first used in the Stockholm Declaration on the Human Environment, adopted June 16, 1972, 67 DEP'T ST. BULL. 116, 118, 11 I.L.M. 1416, 1420, which affirmed the "sovereign right [of states to] exploit their own [natural] resources pursuant to their own environmental policy." The nationalization disputes that surrounded the Stockholm Declaration differed significantly from the intellectual property issues that are the topic of this Note.

50. See supra note 35 . 
in genetic resources. ${ }^{51}$ Effective conservation requires long-term redistributive strategies for the development of LDC economies. Under an Undertakingstyled scheme, however, with no patent protection for biodiversity products, only contractual arrangements with transnational corporations will be available to allow LDC's to exploit these resources financially. The valuation objection to protecting raw germplasm-that its indeterminate usefulness makes it difficult to value in advance ${ }^{52}$ - should lead to an undervaluation of this natural resource given the greater bargaining power of the richer, more developed countries. A property right-such as a patent-allows its holder to accept the risk that its value will change over time. Patent rights would give LDC's the freedom to wager that their biodiversity resources will become more valuable over a longer time horizon. Denied this alternative, LDC's will be forced to accept the lower up-front offers a contractual natural-resource exploitation agreement brings.

Above these problems looms a more practical one: contractual regimes to protect intellectual property rights are easily circumvented, especially when not every player is a party to the contract. Given their generally inadequate law enforcement resources, LDC's may be unable to prevent companies from smuggling out samples of biological material. Furthermore, competing pharmaceutical companies may simply "steal" from each other. Most natural products are not patentable and may be freely copied by the competitors of a company contracting with an LDC..$^{53}$ This threat almost certainly serves to lower the value of the deal to the contracting LDC.

So-called "chemical prospecting" contractual agreements, which appeared on the scene at the same time as the Rio Convention was being negotiated, illustrate the problems inherent in pure contractual regimes. ${ }^{54}$ Perhaps spurred on by deforestation or by a desire to affect the course of the Rio negotiations, at least two U.S. drug companies, Merck \& Co. and Shaman Pharmaceuticals, have contracted with Latin American nations to gain access to virgin biological raw material in exchange for a share in the profits from any resulting products. Both companies intend to file patents on influenza and herpes antiviral agents derived from native plants. Shaman, a small start-up operation with a nonprofit

51. The Bush Administration, it should be noted, seems to have read the treaty this way: "The White House argued that this language [calling on countries to share 'in a fair and equitable way' the results of biochemical research, Rio Convention, supra note 13, art. 15, § 7, 31 I.L.M. at 828] eroded the patent rights of American companies that wish to study the flora and fauna that happen to exist in poor countries." Marcia Coyle et al., U.S. Rio Stance Said to Hurt Competitiveness, NAT'L L.J., June 22, 1992, at 5.

52. See supra note 36 and accompanying text.

53. Drug companies already have many effective strategies to circumvent the exclusion of naturally occurring products from patentability. These strategies, discussed in detail in Part III of this Note, may also help third parties undercut the exclusivity of a contractual agreement to transfer genetic resources from an LDC to a corporate pharmaceutical concern. This subvertibility contributes to the undervaluation of the resource.

54. William K. Stevens, Shamans and Scientists Seek Cures in Plants, N.Y. TIMES, Jan. 28, 1992, at C1. 
arm, plans to deal largely in extracts from materials harvested continuously from LDC's. ${ }^{55}$ Merck, however, paid an up-front $\$ 1$ million "prospector's fee"s6 plus a small royalty $\mathrm{fee}^{57}$ to the National Biodiversity Institute (INBio), a Costa Rican government organ. In exchange, Merck has received the right to exploit a limited territorial area for new drugs, with the cooperation of the government and of indigenous experts who will recover samples of medicinally useful plants that INBio will then forward to the company. ${ }^{58}$ Merck will retain patent rights to products developed under this agreement. ${ }^{59}$

From Merck's point of view, this contract to exchange genetic resources for a share of the profits from their exploitation is made less valuable by the fact that its "exclusive" right to exploit the samples sent it by the Costa Rican government can be undercut by other drug companies. Once Merck's product reaches the market, other drug companies could fairly easily determine the structure of the active chemical ingredient. ${ }^{60}$ These competitors would then be in the same position that Merck had been in after it had processed the original plant samples to determine the structures of their active pharmacological agents. Moreover, because of the naturally occurring substance exception to patentability ${ }^{61}$ Merck might have no recourse to patents to protect the drug it had "exclusively" contracted to develop. Without a guarantee of exclusivity, enforceable only by patent rights accruing to one of the contracting parties, Merck would receive only a slight head start on its competitors in exchange for its prospecting fee and royalty payments. ${ }^{62}$ The

55. Small Companies ... Shaman Pharmaceuticals, PREDICASTS HEALTH BUS., Sept. 27, 1991, at 31.

56. Birds and Bees, ECONOMIST (U.S. Edition), May 30, 1992, Survey Section, at 15, 17.

57. The amount of this royalty has not been disclosed, but one report estimates that it is between one and three percent on any product developed. Pharmaceutical Companies Go "Chemical Prospecting" for New Medicines, supra note 6. Costa Rica promises that it will reinvest fifty percent of these royalties "in conservation." A Merck spokesperson, Jeff Goldstein, claimed in August 1992 that "[b]ecause there are so few [prospecting] agreements[,] it seems that [Merck's deal] is becoming a model." However, he added that screening in this way is a "high-risk venture," and that it is not known whether the company will find anything useful. Id.

58. Stevens, supra note 54 , at $\mathrm{Cl}$. These local experts are the "bushmasters" who collect medicinal plants for the shamans. A typical bushmaster in Belize earns anywhere from two to ten times the typical farmer's income. Id. at C9. Insect samples are also part of the deal. See Coyle et al., supra note 51, at 5.

59. Pharmaceutical Companies Go "Chemical Prospecting" for New Medicines, supra note 6; Graeme Browning, Biodiversity Battle, 24 NAT'L J. 1827, 1828 (1992). These patents, if approved, would be of the sort assigned to compounds that, while occurring in nature, were nonetheless previously unknown in their purified and isolated form and are therefore not subject to the exclusion from patentability of naturally occurring substances. See infra text accompanying notes $80-83$.

60. The ease of reverse engineering chemical structures is the reason trade secret protection would be ineffective for maintaining the exclusivity of such contractual arrangements.

61. See infra Part III.

62. It took Merck eighteen months to isolate its antiviral product from the natural raw materials. Stevens, supra note 54, at $\mathrm{Cl}$. Once the finished product reaches the market, competitors would probably need only a few weeks to determine the chemical structure of the active ingredient by using advanced spectroscopic techniques like 2D-NMR (two-dimensional nuclear magnetic resonance). On 2D-NMR, see generally W. McFarlane \& D.S. Rycroft, Multiple Resonance, 16 ANN. REP. NMR 293 (1985). Simpler technologies (e.g., X-ray crystallography, mass spectroscopy, IR and UV spectroscopy, simple test reactions) can in combination also yield quick results given some idea of a structure with which to begin. In any event, the chemical structure of a pharmaceutical product must ordinarily be published. See 21 U.S.C. 
value of this head start pales beside that of a seventeen-year monopoly on production and use. ${ }^{63}$

The disparity between the potential value of any pharmaceuticals that might be developed as a result of this prospecting agreement and the compensation that Costa Rica would receive presents an economic problem that must be solved by any scheme to create incentives for conservation. The root of this problem is not the undervaluation of Merck's inventive effort. Merck's competitors will have made approximately the same effort to bring their competing analogues to market. Nor is the problem the undercutting of Merck's capital investment. If its antiviral makes it to market, Merck will have underpaid vastly: one million dollars is a small sum weighed against the finances needed to gain regulatory approval for a new drug; and the unofficial royalty figure of one to three percent is small by pharmaceutical industry standards, ${ }^{64}$ even if all that has been gained is a jump on the marketing end. ${ }^{65}$ Rather, the problem is that the total contribution to the general welfare made by the introduction of the drug into the market is being undervalued. It is the LDC's natural resource, the knowledge of the structure of the drug, that is thereby undervalued. The conservation goals of the Rio Convention would be more effectively fulfilled if the LDC's property rights were broad enough to extract the full economic rents from those who benefit from its genetic resource. The LDC should have some form of patent right extensive enough to cover the entire value that the contracting pharmaceutical producer-and any free-riding competitors-gained from the discovery. ${ }^{66}$

$\$ 355(l)$ (1988). Once a competitor has determined the chemical structure, it has to perfect a laboratory synthesis. The time scale for this would probably be slightly longer, perhaps a few months for a moderately complicated molecule. The bulk of the lead time advantage accruing to Merck would come from this delay if the competitor's proposed product were allowed to benefit from the safety and efficacy testing results accumulated by Merck; the latter process ordinarily takes several years, but under the 1984 Drug Price Competition and Patent Term Restoration Act, the process is greatly accelerated if the product being tested is shown to be "bioequivalent" to a pharmaceutical that has been already approved but is no longer on patent. See 21 U.S.C. \$ 355(j) (1988); 35 U.S.C. \$ 271(e) (1988) (defining patent infringement in relation to FDA testing data). Bioequivalent drugs are basically generic-brand versions of previously approved products, equally potent and absorbed into the bloodstream at the same rate. They "are not required to replicate the extensive clinical trials that have already been used in the development of the original, brandname drug," but rather only need satisfy the lesser conditions for approval of "abbreviated new drug applications." Jeffrey Yorke, FDA Ensures Equivalence of Generic Drugs, FDA CONSUMER, Sept. 1992, at 11,14 .

63. Of course, the value of any patent depends upon its scope. In the pharmaceutical industry, a competitor may be able to circumvent the seventeen-year monopoly on the production and use of a patented drug by creating a semisynthetic analogue to that drug. The second half of this Note addresses the thomy issues of patent scope that are raised by this practice. See infra Parts III-IV.

64. See supra note 57. The typical royalty range for undeveloped drug products is two to four percent, and not all biodiversity products will be so risky. Victoria McNamara, Researchers Cash in on Biotech Laws, HousToN Bus. J., July 3, 1989, § 1, at 1.

65. This lead time can, however, be extremely valuable. See infra note 91 and accompanying text.

66. This argument turns on a use-value determination which, like all use-value determinations, is difficult to pin down empirically. Since synthetic pharmaceuticals are much more expensive to bring to market than phytochemical pharmaceuticals, it may be safe to assume that the cost of producing an acceptable substitute sets a very high upper limit on the rent-seeking activity of such LDC resource monopolists. Such valuations involve "the complex types of preferences involved when one is dealing with 
Of course, the disparity between the ex ante payments to the LDC's by the prospecting companies and the returns generated by the rare "find" may be seen as a form of insurance payment, working to protect individual LDC's from the possibility that their phytochemical harvest will produce only valueless duds, while some other countries' plants will bear the few viable drugs found in a given year. ${ }^{67}$ In exchange for the bargain, the transnational drug company assumes this risk, which it may be better equipped to bear than an impoverished LDC would be. The skimming of economic rents from these resources by transnational corporations might be thought to be justified by their assumption of this risk; in fact, such contractual exploitation arrangements, while having a lower overall value to the LDC resource "owners," may in fact fit better into the equitable redistributive scheme envisioned by the Rio Convention, since a larger number of LDC's would be assured of a more regular stream of income. Given the blockbuster-oriented nature of modern drug development, income regularity is a plausible concern. ${ }^{68}$ However, this arrangement also transfers the initiative from the resource holder to those on the marketing end, and it could also redistribute conservation funds to some nations whose resources might be less worth saving. Moreover, a collective national property scheme involving risk-spreading among several LDC's could accomplish the same goals. ${ }^{69}$ All things considered, a deal as one-sided as Merck's appears to be the result of a severe imbalance of bargaining power: the enormous wealth of a multinational corporation matched against the enormous financial need of a developing nation for preserving biodiversity and for developing its own pharmaceutical industry.

uncertain and intertemporal outcomes." W. Michael Hanemann, Economics and the Preservation of Biodiversity, in BlODIVERSITY 193, 197 (E.O. Wilson ed., 1988). This is the origin of the dilemma presented by attempts to put an economic value on biodiversity.

67. Given ex ante valuation problems of this type in voluntary contractual agreements, biotechnology companies' worries are understandable. They fear that the Rio Convention, especially Article 16 and its "equitable sharing" provisions, will allow LDC's to claim a portion of profits retroactively, after development of the drug has progressed to the marketing stage and the attendant huge capital commitment has already been made. See U.S. Biotech Companies Leery of Biodiversity Treaty, supra note 11, at 13A.

68. See Scott Cahill et al., Have Pharmaceutical Companies Missed the Boat on Biotechnology?, MED. MARKETING \& MEDIA, Jan. 1992, at 28, available in LEXIS, Nexis Library, MEDMKT File (stating that blockbuster drugs actually subsidize other drugs and that biotechnology firms have the greatest potential for creating blockbusters).

69. Rights could be assigned to multinational LDC organizations like the Andean League, to multinational economic organizations, or to one of the bodies spawned by the Convention itself. Article 16 of one proposed draft of the Convention apparently contained an explicit option to establish a specialized unit to collect specimens, to evaluate commercial applications of the collected specimens, and, finally, for the Secretariat to apply for intellectual property rights over any discoveries or inventions arising from such evaluations. Royalties would be invested in a fund for preserving biodiversity. These rather paternalistic proposals of the International Union for the Conservation of Nature (IUCN) were eventually rejected. See Draft Articles Prepared by IUCN for Inclusion in a Proposed Convention on Conservation of Biological Diversity and for the Establishment of a Fund for that Purpose with Explanatory Notes, Draft 6, June 1989 (unpublished), cited in Kathryn Rackleff, Preservation of Biological Diversity: Toward a Global Convention, 3 Colo. J. INT'L. ENVTL. L. \& POL'Y 405, 406 n.7 (1992). 
The great difference in value between arrangements for exploiting biodiversity resources which are founded on property rights and those which are not will make the patent (property rights) model far more effective in implementing the redistributive goals of the Rio Convention, at least over the long run. A system based on the patent model would provide the sovereign ${ }^{70}$ within whose territory the biodiversity resource is first found with patent-like rights, ${ }^{71}$ that is, with exclusive rights to enjoin use for an arbitrarily fixed term. ${ }^{72}$ The goal of the system would be to improve the bargaining position of underdeveloped resource holders against the wealthy transnational companies that have the expertise and capital to develop those resources. Exclusive ownership of intellectual property rights would allow LDC's to extract the full economic rents for their resources from the transnational drug companies, which would either have to pay near-monopoly prices or go through the expensive and risky process of creating a synthetic substitute for the natural biodiversity pharmaceutical. At the same time, a drug company could protect its investments in specific biodiversity research by negotiating an exclusive licensing agreement with an LDC that would allow the company to enjoin its competitors from using that genetic resource. Under such a property-rights system, market mechanisms would assure the bargaining position of LDC's without any need for a paternalistic bureaucracy to oversee the resulting licensing arrangements. ${ }^{73}$ Creating such rights on an international

70. The rights could also be held by a group of sovereigns, or by sub-sovereign groups, e.g., indigenous peoples whose collective ethnobotanical knowledge is used to identify useful species. Also, these "patents" need not be limited to LDC sovereigns. Certainly, biodiversity resources do exist in developed countries and will be exploited; the Clinton administration recently created a domestic biological survey project in the Department of the Interior. As It Signs Treaty, United States Calls for Global Protection for Biotech, supra note 12 . This is not problematic to a biodiversity patent scheme; attaching value to biodiversity resources will encourage their conservation wherever they are.

71. In the United States, this type of biodiversity "patent" system might be subject to constitutional attack as granting patent rights to a non-inventive product. To survive constitutional scrutiny, the proposed regime could be implemented via a distinct statute that adds restrictions in order to differentiate the right granted from patent rights, as with the Orphan Drug Act, 21 U.S.C. $\$ \S 360 a a-360 e e$ (1988); see also Genentech, Inc. v. Bowen, 676 F. Supp. 301, 304-05 (D.D.C. 1987) (noting that Orphan Drug Act covers unpatentable products). Such a statute could clearly state that the system is being established pursuant to the Commerce Clause, U.S. CoNST. art. I, $\S 8, \mathrm{cl} .3$, rather than the Copyrights and Patents Clause, U.S. CONST. art. I, $\$ 8$, cl. 8.

72. Because the tropical species relevant for chemical prospecting tend to be restricted in range of habitat, the entire population of a species providing a useful chemical will often be confined within the borders of one country. E.O. Wilson, supra note 9, at 11 . The reasons why these species are less dispersed than their temperate counterparts are discussed in Richard B. Norgaard, The Rise of the Global Exchange Economy and the Loss of Biological Diversity, in BIODIVERSITY, supra note 9, at 206, 209, and in Thernstrom, supra note 1, at B6. Whether or not these chemicals would occur in an unrelated plant species elsewhere is a different question, the answer to which will probably vary depending on how distinctive the chemical structure in question is.

73. Neither less developed countries nor pharmaceutical companies relish the prospect of a supervisory bureaucracy; faced with this alternative, both would prefer a property-rights system. Underdevelopment theorists support property rights as an effective vehicle for encouraging autonomy in the rights holder. See, e.g., Charles A. Reich, The New Property, 73 YALE L.J. 733, 771 (1964). As for the pharmaceutical companies, in the days prior to the Rio Summit one executive was quoted as saying that, while he had not come across any opposition from drug manufacturers to paying royalties to countries for successful drugs derived from their plant species, .... [t] he great concern is that [once the 
scale would, of course, require the municipal legal systems ${ }^{74}$ of the participant nations to manifest a genuine commitment to protecting rights in biodiversity natural resources, as well as a genuine commitment to strong intellectual property protection generally. ${ }^{75}$ Whether the patent system of the United States can provide biodiversity patents with strong intellectual property protection is the question the remainder of this Note will address.

\section{The Natural Products Exception: Has It Already Prepared FirMS TO CIRCUMVENT A BIODIVERSITY PATENT SysteM?}

As it exists today, patent law in most nations excludes from patentability all "products of nature,"76 including chemical structures. Overcoming the obstacle this poses for effective biodiversity patents requires more than adding a new exception to an exception, because the traditional exclusion has prompted pharmaceutical companies to develop strategies to evade the unpatentability of products of nature. These same strategies may also have prepared drug companies to undermine the effectiveness of the biodiversity patents proposed here. This Part begins with an analysis of the naturally occurring substance exception in current patent law. It then examines the "semi-synthetic" methods that pharmaceutical companies already use to evade the spirit of this exception, methods that these companies could potentially use to undermine the spirit of a Rio scheme as well.

convention becomes formally operational] a horrendous bureaucracy will emerge. The result will be that if a company wants to move germplasm out of the country there will be so much form filling and red tape that the exercise will not be worthwhile.

Biodiversity Treaty May Restrict Commercialization, BIOTECHNOLOGY BuS. NEWS, July 3, 1992, available in LEXIS, Nexis Library, BIOBUS File.

74. The transnational patent system, to the extent that it exists at all, is the product of convergence between the municipal patent systems of individual nations, a convergence often motivated by external economic coercion in the form of trade sanctions. (The genuinely transnational system established by the European Patent Convention is one exception.) The two major transnational patent institutions are the World Intellectual Property Organization (WIPO) and the General Agreement on Tariffs and Trade (GATT). The United States, having found WIPO ineffectual in aiding its past efforts to strengthen intellectual property protection worldwide, has generally sought to use GATT as a vehicle for harmonizing world patent systems. The Swiss proposed using GATT to enforce standards established by WIPO, but U.S. policymakers rejected this proposal's continued emphasis on WIPO. Michael B. Smith, The Uruguay Round and the Intellectual Property Agenda, in INTELLECTUAL PROPERTY RigHTS AND CAPITAL FORMATION IN THE NEXT DECADE 163, 166-68 (Charls E. Walker \& Mark A. Bloomfeld eds., 1988).

75. This includes the rights of pharmaceutical manufacturers in nations that undermine or refuse to allow pharmaceutical patents. The Reagan Administration estimated that U.S. businesses lose some $\$ 60$ billion annually to piracy of patents and other intellectual property. Clyde H. Farnsworth, U.S. to Offer Proposals to Fight Piracy, N.Y. TIMES, Feb. 27, 1988, at 38. This amount is of a comparable magnitude to the contemporary estimate of the sum that a biodiversity patent scheme could potentially redistribute: total world pharmaceutical sales were $\$ 127$ billion in 1987. See Robert Teitelman, Global Report on Pharmaceuticals, FIN. WORLD, May 30, 1989, at 54, 55. By some estimates, $50 \%$ of these sales are attributable to natural sources. See supra note 7 and accompanying text.

76. The terms "product of nature," "naturally occurring substance," "natural substance," etc., are used synonymously. 
The patent laws of most nations distinguish "between 'discovery' and 'invention' and exclude mere discovery from patentability." 77 Simply isolating a chemical substance from nature is usually considered unpatentable "discovery." When pharmaceutical companies discover a useful chemical in nature, they often find it more convenient to produce the same substance in marketable quantities through synthetic means. ${ }^{78}$ However, a synthetically produced chemical with the same structure as a natural compound is generally not patentable. In a leading nineteenth-century case that is still good law, the Supreme Court held that a product differing from a substance occurring in nature only in that it is synthetically made does not meet the test for novelty and is therefore unpatentable. ${ }^{79}$

This rule permits an exception: if the product was "previously unknown in its purified and isolated form," it may be patentable as a substance, not just as a purification process. ${ }^{80}$ This exception continues to hold despite the relative ease of most modern purification and isolation processes. Artificially created substances of such higher purity that they "differ not only in degree but in kind" from the identical known natural substance are patentable. ${ }^{81}$ The leading case in this area concerned claims for crystalline vitamin $B_{12}$, ${ }^{82}$ which does not exist in nature because $B_{12}$ crystal structure is undermined by the slightest impurities. At the patented purity level the product is medicinally useful. To qualify for this type of purification patent, the level of purity should ideally be high enough to allow the product to be distinguished "in kind" by the words of the patent claim-here, conveniently, the product could be described as $\mathrm{B}_{12}$ in crystalline form. In addition, the transformed product must demonstrate "unexpected properties."

77. R. Stephen Crespi, Inventiveness in Biological Chemistry: An International Perspective, 73 J. PAT. \& TRADEMARK OFF. SOC'Y 351, 355 (1991).

78. See supra note 62 on the procedure involved.

79. Cochrane v. Badische Anilin \& Soda Fabrik, 111 U.S. 293, $311-12$ (1884) (alternative holding) (citing The Wood-Paper Patent, 90 U.S. (23 Wall.) 566, 593 (1874) (incorrectly cited as 23 How.)).

80. Charles Berman \& Nancy Lambrecht, Can You Patent a Product That Occurs Naturally?, 104 L.A. DAILY J., Feb. 15, 1991, at 7. The European standard allows patentability in cases where the product is "new in the sense that it was not previously available to the public." However, "[n]otwithstanding these generally agreed lines, the standards for patentability may be stricter in some European countries." Carlos M. Correa, Biological Resources and Intellectual Property Rights, 14 EUR. INTELL. PROP. REV. 154, 155 \& n.8 (1992).

81. In re Merz, 97 F.2d 599, 601 (C.C.P.A. 1938). An earlier case held, per Learned Hand, that adrenalin was transformed by the patentee's purification process into a useful drug, "for every practical purpose a new thing commercially and therapeutically." Parke-Davis \& Co. v. H.K. Mulford \& Co., 189 F. 95, 103 (C.C.S.D.N.Y. 1911), aff'd in part and rev'd in part, 196 F. 496 (2d Cir. 1912) (upholding patent on the purified product).

82. Merck \& Co. v. Olin Mathieson Chem. Corp., 253 F.2d 156 (4th Cir. 1958); see also Merck \& Co. v. Chase Chem. Co., 273 F. Supp. 68 (D.N.J. 1967) (upholding same claim).

83. Ex parte Gray, 10 U.S.P.Q.2d (BNA) 1922, 1924 (Bd. Pat. App. \& Int. 1989) (holding recombinant product unpatentable, although purer than product isolated from natural source, because absence of natural contaminants produced no unexpected effect). It is unclear what level of change in form or utility is sufficient to meet these tests. This ambiguity seems to have been intentionally shifted over from the question of what gradation of purity is a sufficient advance. See Olin, 253 F.2d at 164 . 
Pharmaceuticals derived from the plant sources that the Rio Convention aims to protect are unlikely to meet the conditions for patentability in the present system. Since most of these phytochemicals will have been discovered in a plant already known to be medicinally useful (e.g., by native experts in the Merck prospecting agreement), the purified or synthetic pharmaceutical would have to show some qualitative leap in clinical efficacy in order to qualify for a patent under the "unexpected properties" condition.

Precisely because it has been so difficult to obtain patents on synthetic (and therefore mass-producible) versions of naturally occurring pharmaceuticals, the practice of adding small modifications to the chemical structure of the original compound has become widespread. ${ }^{84}$ This process typically involves discovery of the natural compound's chemical structure and the laboratory synthesis to duplicate it. Through a process of trial and error, the patent-seeker then tries to create a "new" chemical that has a slightly different structure but duplicates the beneficial effects of the original.

Three possible explanations account for the pharmaceutical industry's extensive use of this practice. The first is that structural modification of known metabolites has historically been an effective strategy for developing new drugs. ${ }^{85}$ Antibiotics, for example, are often found in nature in an unstable or otherwise therapeutically useless form, which slight chemical structure modifications may convert into a more potent version. ${ }^{86}$ The new compound, if not itself known to be naturally occurring, is-and should be-patentable. Apparently slight structural modifications can also sometimes produce radical changes in the clinical effect of a known metabolite. Steroids are a frequent target of this sort of research, since all the members of this huge class of hormones are based on a common four-ring carbon framework.

Although drug companies may want to claim that a search for "superior biological properties" underlies all aspects of their research, two other explanations lead to the conclusion that such practices are of more dubious social utility. The peculiarities of marketing in the pharmaceutical industry often justify the development of look-alike chemical analogues to existing drugs, despite the huge cost of obtaining regulatory approval for the new variants. Modifying old top-sellers can allow for niche-marketing in profitable and competitive fields, such as tranquilizers. ${ }^{87}$ Incremental improvements may

84. Sometimes the following difficulty is encountered:

[N]aturally occurring chemicals can not be patented once their structures have been published. Active compounds that are discovered and characterized by university researchers are often published in scientific journals before patents are granted. Drug companies are then forced to spend time and money finding novel derivatives with the same effect, so they can patent them.

Medicinal Plants: Pills in a Haystack, ECONOMIST (U.S. Edition), Feb. 24, 1990, at 87. On the treatment of publication generally in the United States, see 35 U.S.C. \& 102(a), (b) (1988).

85. JAMES, supra note 3 , at 62 .

86. Id. at 62-63.

87. PRADHAN, supra note 4 , at $42-45$. 
increase sales in a category when new drugs can be marketed to doctors under the label "new and improved", ${ }^{88}$ firms can take advantage of the old trademark (whose use continues to be protected even after the patent expires) by giving the new versions related marks. These strategies are of significant benefit because the drug business is so marketing-intensive: some $20-25 \%$ of drug company revenues go into advertising. ${ }^{89}$ For this reason, firms "often rush a product to market in order to be first with it and then replace it later" with a more refined relative. ${ }^{90}$ The publicity accruing to technological advances in the medical field and the head start on establishing trademark recognition benefits the product. In the long run, trademark recognition is often the most valuable intellectual property right a pharmaceutical company obtains in a breakthrough drug. ${ }^{91}$

Finally, the desire to evade the product-of-nature patent restriction motivates much of this research. The huge cost of securing FDA approval for a new pharmaceutical compound increases the risks of trying to market a new but non-patentable naturally occurring drug. The effort and delay involved in finding a "novel" derivative with the same effect is often worth the trouble, because this marketed version, and the huge investment required for safety and efficacy testing, can be protected by a patent. ${ }^{92}$ One recent example of this phenomenon involves the drug lovastatin, which blocks the body's synthesis of cholesterol. Lovastatin represented a breakthrough in the control of

88. Id. at 45 .

89. Chudnovsky, supra note 10 , at 190 . This phenomenon is statistically obscured, as "development" takes an ever-increasing share of "research and development" investment dollars. JAMES, supra note 3, at 81. Nonetheless, industry-wide, "overhead and promotion budgets . . . amount to $25 \%$ of sales, vs. R\&D's 16\%." John Carey et al., A Bitter Tonic for Drugmakers? BuS. WK., Mar. 8, 1993, at 84, 84.

90. PRAdHaN, supra note 4 , at 45 (citing MiCKey C. SMITH, PRINCIPLes of PhaRMaceutical MARKETING 133 (2d ed. 1975)).

91. All pharmaceuticals have a chemical name, which is an intricate formal description of the actual chemical structure in words (e.g., 2,4-pyrimidinediamine, 6-(1-piperidinyl)-,3-oxide), a generic name which is a shortened version commonly used by scientists in most writings (e.g., minoxidil), and a trademarked or brand name (e.g., Rogaine or, in Europe, the more descriptive Regain) for consumers, including doctors. See infra note 95 for another example. Advertisements to doctors tend to concentrate on the trademark names, because of their unlimited length of protection-by the time a drug reaches the market it may only have a few years remaining on its patent protection, often too short a period of time in which to recoup the investment made. Forty percent of all trademarks worldwide attach to pharmaceuticals and associated goods. Chudnovsky, supra note 10, at 190-92. In absolute terms, this covers 50,000-80,000 trade names; for 700 different drugs in the U.S. market there are some 20,000 trade names. Worldwide the average is 70 per drug. Aurelie von Wartensleben, Major Issues Concerning Pharmaceutical Policies in the Third World, in PHARMACEUTICALS AND HEALTH IN THE THIRD WORLD, supra note 10, at 169, 170.

92. As of 1985 , it cost an average of $\$ 94$ million to prove a single drug safe and effective. JAMES A. DuKe, HANDBOOK OF NORTHEASTERN INDIAN MEDICINAL PLANTS, at xi (1986). According to the Pharmaceutical Manufacturers' Association, the total cost of bringing a drug to market today is on average $\$ 231$ million. Rovner, supra note 11 . These costs are often cited as a reason for the lack of interest displayed by U.S. manufacturers towards biodiversity drug sources. See, e.g., DuKE, supra, at xi (citing the high cost as "one simple reason, if not the only reason, that the pharmaceutical companies in the U.S. prefer to come up with synthetic compounds which they can patent, even though the synthetic may be a copycat, template, or derivative of the naturally occurring compound"). 
hypercholesterolæmia when it was discovered in $1980 . .^{93}$ Over 8000 strains of microorganisms were tested in the search for a drug to block the enzyme HMG CoA from converting acetate into squalene, a key reaction in the synthetic route the body uses to manufacture cholesterol. ${ }^{94} \mathrm{~A}$ fungal metabolite, lovastatin ${ }^{95}$ (pictured in Figure 1), was the first effective inhibitor of HMG CoA found. Lovastatin's function derives from the fact that its physical structure makes it attractive to the spot on the enzyme that ordinarily attracts its natural substrate, acetate. ${ }^{96}$ Merck, the first to discover this characteristic of lovastatin, used a general knowledge of enzyme behavior to surmise what was later discovered to be true: that the dihydroxyl group (at the top of the molecule in Figure 1) was crucial to the "structural activity relationship" with the enzyme. ${ }^{97}$ This meant that the lower end of the molecule could probably be modified slightly without destroying the HMG CoA-inhibiting effect. Merck added a methyl group ${ }^{98}$ to this nether-end and called the "semi-synthetic" resulting compound "simvastatin" (pictured in Figure 2)..$^{99}$

Merck has chemical structure patents on both drugs and has marketed them simultaneously since simvastatin's market introduction on January 13, 1992. ${ }^{100}$ Bristol-Myers Squibb has also marketed an HMG CoA inhibitor

93. A.W. Alberts et al., Mevinolin: A Highly Potent Competitive Inhibitor of Hydroxymethylglutarylcoenzyme A Reductase and a Cholesterol-lowering Agent, 77 PROC. NAT'L ACAD. SCI. USA 3957 (1980). A Merck group received U.S. Patent No. 4,231,938 on their discovery of lovastatin, then called "Mevinolin," which they had derived from the microfungus Aspergillus terreus. A Japanese group simultaneously discovered the same drug and dubbed it "Monacolin $\mathrm{K}$ " after the bacterium, Monacus ruber, from which they had derived it. See Akira Endo, Monacolin $K$, A New Hypercholesterolemic Agent Produced By A Monascus Species, 32 J. ANTIBlotics 852 (1979); Akira Endo, Monacolin K, a New Hypercholesterolemic Agent That Specifically Inhibits 3-Hydroxy-3-Methylglutaryl Coenzyme A Reductase, 33 J. ANTIBIOTICs 334 (1980). Aspects of the discoveries that the Japanese group reported are protected by U.S, Patent No. $4,323,648$.

94. FJ. ZeElen, Medicinal Chemistry of Steroids 56 (1990). HMG CoA is 3-hydroxy-3methylglutaryl coenzyme A reductase. Id.

95. "Lovastatin" is the generic name, "Mevacor" the brand name/trademark, and " $\left[1 \mathrm{a}\left(\mathrm{R}^{\mathrm{x}}\right), 3 \alpha, 7 \beta, 8 \beta\right.$ $\left.\left(2 S^{x}, 4 S^{x}\right), 8 a \beta\right]$-2-methylbyutanoic acid 1,2,3,7,8,8a-hexahydro-3,7-dimethyl-8[2-(tetrahydro-4-hydroxy-6-oxo2H-pyran-2-yl)ethyl]-1-naphthalenyl ester" the chemical name. Id. at 70.

96. This spot is called the "active site." On the functioning of enzymes generally, see ALBERT L. LEHNINGER, PRINCIPLES OF BIOCHEMISTRY 207-43 (7th ed. 1982). Lovastatin has 10,000 times the affinity of the natural substrate for HMG CoA's active site. ZEELEN, supra note 94, at 56.

97. ZEELEN, supra note 94, at 56; Ta-Jyh Lee, Synthesis, SARs and Therapeutic Potential of HMGCoA Reductase Inhibitors, 8 TRENDS PHARMACOLOGICAL SCI. 442 (1987).

98. A methyl group is the smallest of the alkyl groups, the most stable class of carbon-containing functional groups in organic chemistry.

99. ZEELEN, supra note 94, at 56-57. Simvastatin is marketed under the trade name "Zocor." Merck Submits NDA for Treatment of Elevated Serum Cholesterol, PR NEWSWIRE, Oct. 16, 1987, available in LEXIS, NEXIS Library, PRNEWS File [hereinafter Merck Press Release] (release by Eleanor Paradowski of Merck).

100. Alice Cantwell, Merck to Introduce Drug to Lower Cholesterol Levels, J. CoM., Jan. 9, 1992, at 7A. Simvastatin illustrates the long time frame required to introduce a new pharmaceutical into the market: Merck had first filed the patent application for simvastatin in 1986 and had submitted the FDA New Drug Application (NDA) in October 1987, Merck Press Release, supra note 99, years before it began marketing the drug in 1992. It appears that the new level of purity of lovastatin was such that, for practical purposes, it did not "previously exist." (The fact that the fungus probably did not have an LDC source also makes this example somewhat less than perfect.) The patent claims that the microfungus involved in the 


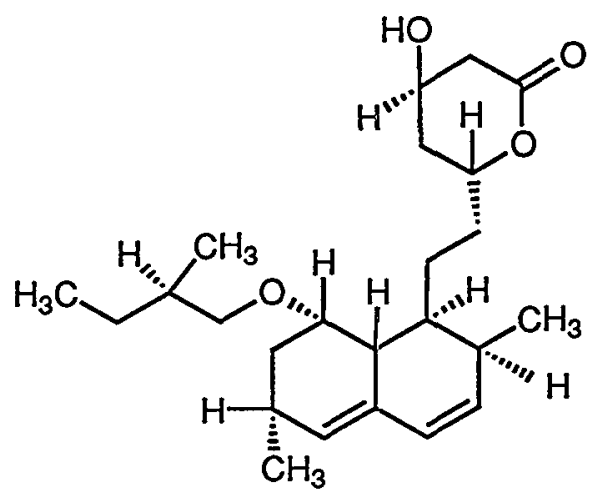

\section{Lovastatin}

FIGURE 1.

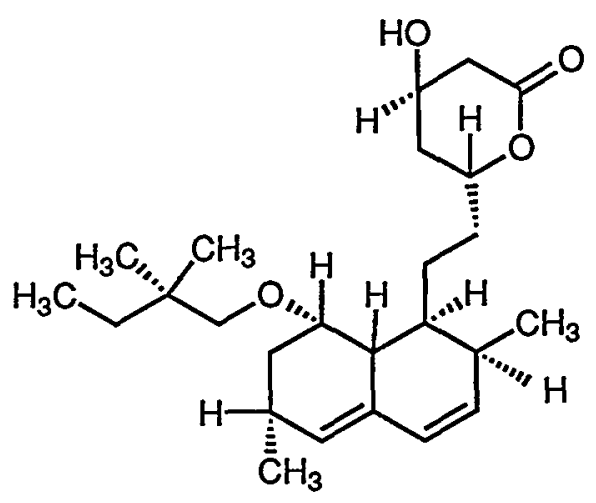

Simvastatin

FIGURE 2. as well as the cultivation/fermentation (i.e., natural) processes for making them. 
under the trade name "Pravachol." 101 According to an independent analyst, "Pravachol, Mevacor [lovastatin], and Zocor [simvastatin] are functionally compatible; none has an inherent chemical advantage."102 John LaRosa, the head of the AMA Cholesterol Task Force, predicts that pricing will increasingly determine market share as more HMG-CoA reductase inhibitors come onto the market, "unless there is some clinically significant differentiation - and there doesn't really seem to be."103

\section{RESPONSES TO THE PROBLEM OF COPYCAT SUBSTANCES}

Merck's patent on simvastatin's structure shows how easy it is to evade the naturally occurring product exception. Patents on drugs do not attach to the specific biological activity that they have-which is in any case very difficult to determine with anywhere near the certainty that we have in our determinations of chemical structures. Rather, patents attach to the exact chemical structure of the drug, allowing pharmaceutical companies to violate the spirit of the natural products exception, which is intended to preclude patent protection for mere discovery - that is, for simply finding something that exists in nature, without any extraordinary search. In our example, the essential discovery was that structures bearing the dihydroxyl head ${ }^{104}$ of the lovastatin molecule fit into the active site of an enormously complex enzyme, thereby inhibiting its natural function. Protecting this aspect of the discovery must be the goal of a biodiversity patent scheme if it intends to value accurately the contribution of these natural resources to the progression of science and to the general welfare. Lovastatin is therefore a model for the sort of original discovery whose contribution to welfare must be fully protected under the Rio

101. Melissa Shon, The Big Issue: Explosive Growth in Cholesterol-Reducing Therapies is Piquing Drug Firms' Interest and Unleashing Price Competition, CheMICAL MARKeTING REP., Mar. 9, 1992, at SR36. Fear of igniting a patent litigation war often inhibits pharmaceutical companies from pursuing claims against their competitors when the stakes are small. Pravachol might be found to infringe on Merck's compounds if a suit were brought, but lovastatin itself might be found to fall under the naturally occurring substance exception in the course of this litigation. Since such cribbing is common in the pharmaceutical industry, Squibb might respond by suing on all of the patents it held which Merck had subsequently infringed. Given the marketing jump and free media attention Merck had with "Mevacor," it probably will choose not to pursue any claims of infringement for these reasons. Annual sales for all cholesterol-lowering drugs were projected to be \$1.6 billion in 1992, with Merck's "Mevacor" (lovastatin) holding $61 \%$ of the market. Id. "Pravastatin" (another name for Pravachol) is also a "natural fermentation product," i.e., it is manufactured by bacteria. See U.S. Patent No. 4,857,546. The same drug is marketed in Japan by Sankyo under the name "Mevalotin," a product of discoveries simultaneous with lovastatin's. See supra note 93. Because Sankyo had little overseas marketing experience, it licensed the drug to Bristol-Myers Squibb for release in the United States. Japan's Medicine Men Take Aim, ECONOMIST (U.S. Edition), Mar. 2, 1991, at 61, 61; see also Joseph Weber, Merck Needs More Gold from the White Coats, Bus. WK., Mar. 18, 1991, at 102, 104 (reporting that "Prava," another name for Pravastatin/Pravachol, was scheduled for U.S. release in late 1991).

102. Shon, supra note 101 (citing Hemant Shah). Shah was "a Merck marketing veteran." Weber, supra note 101 , at 103 .

103. Shon, supra note 101 (emphasis added).

104. See supra text accompanying note 97. 
Convention, whereas simvastatin is a model for the sort of de facto infringer which not only deserves no patent protection of its own, ${ }^{105}$ but whose use should also be an actionable patent infringement under a Rio-inspired patent scheme.

The remainder of this Note begins by exploring the three features of existing patent law that might protect a natural product's chemical structure patent from semi-synthetic pretenders. The first involves a special type of original claim, a "Markush claim," capable of encompassing within its literal scope the whole class of chemical structures to which the natural product belonged. The second is the doctrine of obviousness, which might permit rejection of claims for a copycat substance, if the state of knowledge in the field before its creation rendered it obvious. The third is the doctrine of equivalents, which allows an ex post extension of an original claim to encompass the area covered by a newer compound, based on an after-the-fact finding that the new substance performs the same practical function as the one first claimed. Unfortunately, each of these doctrines, as applied today, is inadequate to accomplish the goals of the Rio Convention. This Note therefore concludes by proposing some fundamental changes in the system of patents on chemical structures that could potentially provide full protection for the fruits of biological diversity.

\section{A. Original Claims Utilizing Markush Groups}

One way to preempt the copycat infringer problem is to state the original literal claim for the naturally occurring pharmaceutical as a "Markush claim" that includes all variants expected to share exactly the same utility. The Markush doctrine evolved in response to our patent system's now-defunct prohibition on the use of alternative language in the wording of patent claims. For example, a claim on a new type of bottle could not list the material as "glass or plastic," but would rather have to use a single generic term that encompasses both. ${ }^{106}$ However, there is often "no commonly accepted generic expression which is commensurate in scope with the field which the

105. Even if a copycat drug such as simvastatin were found not to infringe the original patent, it might still have no value without a distinct patent of its own, because a pharmaceutical company might not be willing to invest the capital needed for FDA testing, see supra note 92 , without being able to rely on a patent to protect its product from literal copying. This assumes, however, that any semi-synthetic drug would have to go through a full new-drug application for FDA approval, and not the cheaper, abbreviated application process allowed for generic versions of old drugs whose patents have expired. See supra note 62. Although this seems likely under current law, any decision on this matter is subject to administrative discretion. See 21 U.S.C. $\$ 355(j)(2)(C)(1988)$.

106. 2 DONALD CHISUM, PATENTS $\$ 8.06[2]$ (1992). The original purpose of the doctrine was to avoid the "difficulty or impossibility of determining the precise limits of the alleged invention"” if a patent claim for such an invention could use alternative language. Id. \$ 8.06[2][a] (quoting Ex parte Reid, 15 Off. Gaz. Pat. Office 882 (Comm'r Pat. 1879)). 
applicant desires to cover."107 In such cases, the applicant may use a "coined subgeneric group" to describe the elements he wishes to claim-for example, a chemical synthesis might be described as involving, at one stage, material selected from "'a group consisting of reactants $x, y$, and $z$." 108

Markush claims for chemical compounds "routinely embrace minor variations on the basic structure the inventor [has] discovered. For example, a patentee might claim a compound of structure 'Atom 1-Atom 2-Sidegroup,' where 'Sidegroup' is defined in the claim as including either ' $\mathrm{N}-\mathrm{O}-\mathrm{O}-\mathrm{H}$ ' or ' $\mathrm{N}-\mathrm{H}_{2}$."' 109 In the lovastatin/simvastatin example, it might be useful to identify the discovery as the basic active structure common to the molecules (the dihydroxyl head), attached to any one of a group of sidegroups (inert tail ends). The primary difficulty with this solution is that the applicant would have to guess which species of broadly inert compounds could be expected to have no effect on the drug's basic (HMG-CoA inhibiting) function when attached to the core molecule, because seeking proof would delay the application for the patent, and thus the disclosure of the invention, until after tests had been conducted. ${ }^{110}$ Several years elapsed between the discovery of lovastatin and the discovery of its very close analogue simvastatin - by no means an insignificant potential delay in the introduction of a breakthrough drug. In addition, the late 1980's saw the discovery of several other synthetic compounds which share the active part of the lovastatin structure and have similar in vitro activity, but differ radically in the structure of the lower part of the molecule. ${ }^{11}$ Such radical differences are problematic for a Markushtype claim, since " $[t]$ he materials set forth in the Markush group ordinarily must belong to a recognized physical or chemical class or to an art-recognized class." 112 The variety of inactive elements that could be substituted into the

107. Patent \& Trademark OfF., U.S. Dep'T of Commerce, Manual of Patent Examining PRoCEDURE $\$ 706.03(y)$ (5th ed. 14th rev. 1992) thereinafter MANUAL OF PATENT EXAMINING PROCEDURE].

108. 2 CHISUM, supra note $106, \S 8.06[2]$. This type of claim was first sanctioned in Ex parte Markush, 1925 C.D. 126, 340 Off. Gaz. Pat. Office 839 (Comm'r. Pat. 1925).

109. Robert P. Merges \& Richard R. Nelson, On the Complex Economics of Patent Scope, 90 Colum. L. REV. 839, 897 n.261 (1990).

110. See MANUAL OF PATENT Examining Procedure, supra note 107, $\$ 715.03$ (stating that priority cannot be obtained by claiming, subsequent to PTO review, a disclosed but unclaimed member of the Markush group, i.e., an element similar to those disclosed as part of Markush group at time of filing claim, but not actually included in that group). Guessing at the probable effect (or lack of effect, in this case) on the activity of proposed members of the Markush group may be difficult. "Markush claims must be provided with support ... for each member of the ... group. Where the constitution and formula of a chemical compound is stated only as a probability or speculation, the disclosure is not sufficient to support claims identifying the compound by such composition or formula." Id. $\S 608.01$ (p).

111. ZEELEN, supra note 94, at 56-57; G.E. Stokker et al., 3-Hydroxy-3-methylglutaryl-coenzyme A Reductase Inhibitors, 29 J. MEDICINAL CHEMISTRY 170 (1986) (discovered by Merck); E. Baader et al., Synthesis of a Novel HMG-COA Reductase Inhibitor, 29 TETRAHEDRON LETTERS 929 (1988) (by Hoechst); N. Balasubramanian et al., A Potent, Tissue-Selective Synthetic Inhibitor of HMG-CoA Reductase, $32 \mathrm{~J}$. MEDICINAL CHEMISTRY 2038 (1989) (by Bristol Myers).

112. Manual of Patent Examining PRoCEDURE, supra note $107, \S 706.03(\mathrm{y})$. Even in process or combination (multiple compound) claims, members of the group must 
core lovastatin structure may be greater than our patent system is ready to allow within the scope of one claim.

\section{B. Obviousness}

The European Patent Office (EPO) employs an obvious desideratum test for rejecting patents on inventions that are "obvious to try." ${ }^{113}$ This, the English "Cripps test," applies to an invention when it is "for all practical purposes obvious to any skilled chemist in the state of chemical knowledge ... that he could manufacture valuable therapeutic agents" by making the product claimed by the process claimed. ${ }^{114}$ The first in the race to realize something "obvious to try" has not earned a broad legal monopoly ${ }^{115}$ Unfortunately, American courts do not acknowledge this logic, and therefore researchers sometimes file a U.S. patent application before the completion of all actual experimental work. ${ }^{116}$

Where a claim is part of a "logical progression from what has gone before," 117 as when a chemical structure differs slightly from a known structure in a manner thought to be unlikely to cause radical changes in the utility of the substance, the EPO finds inventiveness only if properties "flow from the structure in an unpredictable manner. Inventiveness is therefore a combination of a structure and an unexpected utility or degree of utility." In analogous American cases, a showing of "unexpected properties" has been required for patentability where a sufficient structural similarity exists. Sufficiency is determined by the patent examiner's view of whether "one skilled in the relevant chemical art [would have] the motivation to make close

possess at least one property in common which is mainly responsible for their function in the claimed relationship, and it is clear from their very nature or from the prior art that all of them possess this property. While in the past [this test] was applied as liberally as possible, present practice which holds that claims reciting Markush groups are not generic claims . . may subject the groups to a more stringent test for propriety of the recited members.

Id.; see also id. $\S 803.02$ (discussing "unity of invention," found to exist where the compounds listed "(1) share a common utility and (2) share a substantial structural feature disclosed as being essential to that utility"). In In re Schechter, the Court of Customs and Patent Appeals stated the principle thus in the context of chemical structure claims: The Markush group is acceptable "where the substances grouped have a community of chemical and physical characteristics which justify their inclusion in a common group, and such inclusion is not repugnant to the principles of scientific classification." 205 F.2d 185, 189 (C.C.P.A. 1953) (emphasis added). Thus, a Markush group for lovastatin-type compound tail ends including "all alkyl groups shorter than four carbons," see supra note 98 , would be acceptable, but one including all the many complex and unclassifiable inert substituents that would function probably would not.

113. The U.S. Patent Office has utilized this standard in the past. See, e.g., In re Tomlinson, 363 F.2d 928, 930 (C.C.P.A. 1966).

114. Sharpe \& Dohme Inc. v. Boots Pure Drug Co., 45 R.P.D. \& T.M. 153, 173, 176 (C.A. 1927).

115. Crespi, supra note 77, at 361 (discussing In re Genentech Inc., 1989 R.P.D. \& T.M. 147, a British case holding a product-by-process claim to be obvious in light of knowledge about the structure of the final product).

116. Paul H. Eggert, Uses, New Uses and Chemical Patents-A Proposal, 51 J. PAT. OfF. Soc'Y 768, 781 (1969).

117. Crespi, supra note 77 , at 351 .

118. Id. at 353. 
relatives ... of the prior art compound(s)."119 If two compounds have a sufficient structural similarity, a prima facie case of obviousness is established-so long as some information in the prior art specifically motivates or suggests the changes. ${ }^{120}$ Evidence of similar utility would merely add weight to this prima facie case.

The motivation requirement makes it harder to establish obviousness in the United States. Here, a patent application may not be rejected as obvious simply because the claimed invention was "obvious to try." In In re O'Farrell,"121 the court cited two situations it had in mind as merely obvious to try but not obvious under American patent law:

In some cases, what would have been "obvious to try" would have been to vary all parameters or try each of numerous possible choices until one possibly arrived at a successful result, where the prior art gave either no indication of which parameters were critical or no direction as to which of many possible choices is likely to be successful. In others, what was "obvious to try" was to explore a new technology or general approach that seemed to be a promising field of experimentation, where the prior art gave only general guidance as to the particular form of the claimed invention or how to achieve it. $^{122}$

Although look-alike pharmaceuticals such as simvastatin will frequently be "obvious to try" in this sense, they will rarely be so "obvious" as to justify the denial of a new patent under the narrow American standard of obviousness, which applies only when the prior art allows one to predict the effects of specific structural modifications. However, the way in which any sort of structural modification will affect the utility of a pharmaceutical is hard to predict ahead of time, ${ }^{123}$ since even small structural changes have been known to cause radical shifts in utility. As a result, obviousness will provide little protection for Rio-inspired patents on biodiversity resources against de facto infringement by copycat compounds.

119. In re Dillon, 919 F.2d 688, 696 (Fed. Cir. 1990) (emphasis added), cert. denied, 111 S. Ct. 1682 (1991).

120. On "suggestion," see In re Ball Corp., 18 U.S.P.Q.2d (BNA) 1491, 1492 (Fed. Cir. 1991). On these tests generally, see James W. Badie, "Motivation" or "Obvious to Try"-Is There a Difference? Is It a Proper Test of Obviousness?, 75 J. PAT. \& TRADEMARK OFF. SOC'Y 54, 61-66 (1993).

121. 853 F.2d 894 (Fed. Cir. 1988).

122. Id. at 903 (citations omitted).

123. No prima facie case of obviousness is established when the prior art does not allow one to predict similarities in utility on the basis of structural similarities. In re Kuderna, 426 F.2d 385, 389-90 (C.C.P.A. 1970). 


\section{Equivalents}

The equitable doctrine of equivalents effectively extends patent rights to cover products that do not infringe upon the literal terms of the original patent claim but that nonetheless perform "substantially the same function in substantially the same way to obtain the same result" as the patented invention. ${ }^{124}$ Under this standard, establishing the functional equivalence of "look-alike" drugs requires claimants to prove not only that the clinical effects of the drugs are identical, but also that the biological mechanisms triggered by them are the same. Sometimes courts infer such equivalence in biological activity from structural similarities. ${ }^{125}$ Unfortunately, even under the most generous standards of legal proof, it is difficult to establish that two different structures function by exactly the same mechanism, even when (as in the case of the lovastatin family and its inactive tail-end) information about the enzyme and substrate geometries reasonably indicates that a similar biological mechanism is at work. ${ }^{126}$ Because the doctrine of equivalents may be used to expand the scope of the original patent monopoly retroactively, courts have traditionally tried to limit its application by relying on putatively objective standards, such as structure. As noted in the previous Section, the fact that tiny structural modifications have sometimes resulted in important pharmaceutical innovations may lead courts to err on the side of caution and to limit findings of equivalents. ${ }^{127}$

While devices such as Markush groups are useful for expanding the literal scope of a chemical structure patent, the doctrine of equivalents makes it

124. Machine Co. v. Murphy, 97 U.S. 120, 125 (1878); see also Graver Tank \& Mfg. Co. v. Linde Air Prods. Co., 339 U.S. 605, 608 (1950). In Pennwalt Corp. v. Durand-Wayland, Inc., 833 F.2d 931 (Fed. Cir. 1987), cert. denied, 485 U.S. 961 and 485 U.S. 1009 (1988), the Federal Circuit appeared to substantially modify this standard for finding equivalents by establishing the so-called "all-elements rule": "Every claim element or its equivalent must be present in an accused device for that claim to read on the accused device." William E. Player, Elemental Equivalence: Interpreting "Substantially the Same Way" Under Pennwalt After Corning Glass, 71 J. PAT. \& TRADEMARK OFF. SOC'Y 546, 546 n.3 (1989) (citing 4 ChIsum, supra note 106, $\S 18.03[4]$ ). Pennwalt seemed to sound the death knell of the doctrine of equivalents by merging literal infringement and equivalent infringement; the same features used to defeat literal infringement were being used to defeat a finding of equivalents. 833 F.2d at 947 (Bennett, J., dissenting in part). Subsequent decisions have, however, limited this result. See, e.g., Corning Glass Works v. Sumitomo Elec. U.S.A., Inc., 868 F.2d 1251, 1259-61 (Fed. Cir. 1989). In any event, the potential impact of Pennwalt on patents involving chemical products is uncertain, since chemical structure claims are usually not distinguishable into separate elements to the same degree that mechanical inventions are.

125. In In re Anthony, 414 F.2d 1383, 1386 (C.C.P.A. 1969), the court held that a stereoisomer of a previously patented compound was not patentable without a showing of novel biological effect.

126. See supra text accompanying note 97 .

127. Note that under this standard, a showing of any slight difference in clinical function would protect a claimed look-alike compound from a finding of equivalents. The court in In re Georges Jolles, 628 F.2d 1322 (C.C.P.A. 1980), found that a claimed anticancer agent, though structurally similar to a previously patented anticancer compound, was slightly more efficacious in causing remission in early clinical trials- $53 \%$ of the patients went into remission, as opposed to some presumably lower number for the prior-art drug. This provided the "requisite utility" to overcome the obvious structural similarities and avoid a finding of equivalents. The court emphasized that the structural similarities did not make Jolles' compound prima facie obvious under the prior art. 
possible to expand the effective scope of a patent beyond the bounds of its literal claim. The extent of the effective expansion typically reflects the nature of the original invention. ${ }^{128}$ Donald Chisum describes three categories of original claims: "pioneers, entitled to a broad range of equivalents; marked improvements, entitled to a substantial range of equivalents; and narrow improvements, entitled to a limited or no range of equivalents." 129 A newly discovered compound occurring in nature should qualify as one of Chisum's pioneers "because, unlike new compounds produced through chemical synthesis, a newly discovered [substance] having a novel activity or 'function' could not have been 'predicted' or even contemplated prior to its actual discovery." 130 Thus, pharmaceuticals derived from biodiversity resources should be entitled to a broad range of equivalents.

Two problems complicate the use of equivalents doctrine to protect an LDC's equitable interest in its naturally occurring pharmaceuticals from lookalike piracy. The first is judicial uncertainty concerning so-called "new or unknown equivalents." Under older cases, the term "new equivalent" applies to an invention which substitutes some newly discovered element, ingredient, or technology into the original invention without changing its utility or function. Traditionally, such "new equivalents" were held not to infringe a patent on the original invention, and their use could therefore not be enjoined under the doctrine of equivalents. ${ }^{131}$ Under this traditional approach, the doctrine of equivalents would not protect the holders of biodiversity patents if semi-synthetic knock-offs were deemed to be non-infringing "new equivalents." More recently, however, lower federal courts have taken the opposite position: the fact that a newly created substance did not exist at the time of an earlier claim does not preclude a finding that the new compound is an infringing equivalent of the old. ${ }^{132}$ The Supreme Court has declined to

128. See Jeffrey P. Kushan, Protein Patents and the Doctrine of Equivalents: Limits on the Expansion of Patent Rights, 6 HIGH TECH. L.J. 109, 129 n.74 (1991); see also Ziegler v. Phillips Petroleum Co., 483 F.2d 858, 869-70 (5th Cir. 1973).

129. 4 ChISUM, supra note $106, \S 18.04[2]$.

130. Kushan, supra note 128 , at 138 (discussing proteins).

131. Gould v. Rees, 82 U.S. (15 Wall.) 187, 192-93 (1872). But see Edison Elec. Light Co. v. Boston Incandescent Lamp Co., 62 F. 397 (C.C.D. Mass. 1894) (holding new equivalent infringing). Paradoxically, some patent-scope minimalists view the doctrine of equivalents as fulfilling its "sole legitimate function" when applied to "new equivalents," where, they believe, the doctrine protects the reliance interests of patentees by "ensur[ing] that patent protection is not eviscerated by technology developed after the patent issues when claims that would cover the technology literally are unavailable under reissue and were unavailable during the original prosecution." Martin J. Adelman \& Gary L. Francione, The Doctrine of Equivalents in Patent Law: Questions That Pennwalt Did Not Answer, 137 U. PA. L. REv. 673, 728 (1989).

132. See Merges \& Nelson, supra note 109, at 855 n.74 (citing Texas Instruments, Inc. v. United States Int'l Trade Comm'n, 805 F.2d 1558, 1563 (Fed. Cir. 1986)); see also Hughes Aircraft Co. v. United States, 717 F.2d 1351, 1365 (Fed. Cir. 1983) (citing Bendix Corp. v. United States, 600 F.2d 1364, 1382 (Ct. Cl. 1979); Decca Ltd. v. United States, 544 F.2d 1070, 1080-81 (Ct. Cl. 1976); and Eastern Rotorcraft v. United States, 397 F.2d 978, 981 (Ct. Cl. 1968)). These more recent lower court opinions depart from the approach of older Supreme Court cases, such as Graver Tank \& Mfg. Co. v. Linde Air Prods. Co., 339 U.S. 605 (1950). 
review Federal Circuit decisions that state the currently prevailing view that new technologies can constitute equivalents. ${ }^{133}$ Thus, today the doctrine of equivalents probably could be applied to look-alike pharmaceuticals that are developed after a naturally occurring substance has been patented.

The second objection is more intractable, however, because it is directed against the entire doctrine of equivalents: since similarities between the structure and functioning of two related chemicals are always a matter of degree open to subjective evaluation, ${ }^{134}$ the doctrine provides no clear limit to the post hoc expansion of a monopoly right originally granted for disclosure of a discrete discovery. To a greater or lesser extent, every finding of equivalents dispenses with the requirement of literalness for patent applications and extends monopoly protection to what is, in the view of the deciding court or administrative body, the non-literal substance of the original invention. In the words of Learned Hand, a finding of equivalents stretches the literal terms of a patent claim to "cover more than their meaning will bear." 135 The doctrine of equivalents denies form in a field that is generally characterized by literal formalism.

These objections suggest that findings of equivalents should be limited to a select class of cases, even for the category of "pioneer" patents that includes most phytochemical discoveries. Under the "prospect theory" of patent scope developed by Edmund Kitch ${ }^{136}$ and elaborated by Robert Merges and Richard Nelson, ${ }^{137}$ patents should be construed to have the broadest scope, and thus to be entitled to the broadest class of equivalents, when they cover inventions in fields characterized by the "discrete invention model."138 These types of inventions are "discrete and well defined," and, while the original breakthrough may be subject to piecemeal improvement,

it is implicit that [the invention] does not point the way to wide ranging subsequent technical advances. It does not define any broad prospect. ... For inventions and industries like these, while tight and broad control of a particular invention may enable a firm to profit handsomely, possession by that firm of a proprietary lock on the

133. See, e.g., United States v. Decca Ltd., 454 U.S. 819 (1981), denying cert. to 640 F.2d 1156 (Ct. Cl. 1980).

134. As Learned Hand noted, going beyond the literal terms of a patent to cover "“substantially similar' variants" of the original claim "is always a question of degree, and courts have differed, and always will differ, as to the allowable latitude in a given instance." Royal Typewriter Co. v. Remington Rand, Inc., 168 F.2d 691, 694 (2d Cir.), cert. denied, 335 U.S. 825 (1948).

135. Id. at 692 . Patents tend to be construed as widely as possible during the examination period and as narrowly as possible afterwards, a two-stage selection in favor of literal interpretation. See Giles S. Rich, Extent of Protection and Interpretation of Claims-A U.S. Perspective, 21 INT'L REV. INDUS. PROP. \& COPYRIGHT L. 497, 499, 503 (1990).

136. Edmund W. Kitch, The Nature and Function of the Patent System, 20 J.L. \& ECON. 265, 266, 276 (1977).

137. Merges \& Nelson, supra note 109.

138. Id. at 880 . 
invention is not a serious hindrance to inventive work by many other firms. ${ }^{139}$

In these discrete invention fields-such as pharmaceuticals-new inventions generally do not appropriate prior art elements whole and, conversely, are rarely amenable to incorporation as elements of some other, subsequent invention. ${ }^{140}$

In discrete invention fields, construing the scope of patents broadly-and therefore finding equivalents readily-provides a strong incentive for the creation of new inventions. At the same time, the broad scope of patents in these fields does not have the negative economic effect of discouraging work towards improvements on the breakthrough. This is because breakthroughs in a "discrete invention" field are usually amenable to incremental improvement that can be efficiently orchestrated by a single rights holder but are not amenable to incorporation in a wide range of subsequent inventions. In this respect, discrete invention fields stand in marked contrast to fields characterized by "cumulative invention," in which "advances build on and interact with many other features of the existing technology. ... [ [ ] nventions may enhance some feature of a prior 'dominant design,' or they may be incorporated into subsequent inventions, or both." cumulative invention predominates, it is unlikely that one firm, if given broad patent rights, could orchestrate the further development of an initial breakthrough as efficiently as the competitive market can. Narrow judicial interpretations of patent scope foster this kind of competitive market by sharply delimiting the monopoly granted to pathbreaking or pioneering patent claims. This type of market competition is unnecessary in discrete invention fields, because pioneering inventions in those fields usually cannot be incorporated into a wide range of subsequent inventions, but can instead only be incrementally improved in a manner that a single rights holder can orchestrate.

Thus, the post hoc expansion of patent scope through findings of equivalents is inefficient only in fields characterized by cumulative advances in technology, rather than by discrete invention. But most pharmaceutical advances resulting from phytochemical research are in fact insular discoveries that are not predictably related to future advances or improvements, and they therefore do not fit the cumulative technologies model. Because of "the complex and unpredictable relationship between chemical structure and function,"142 pharmaceuticals belong in the "discrete inventions" category. ${ }^{143}$

139. Id. at $880-81$.

140. Id.

141. Id. at $881-82$ (citations omitted).

142. Id. at $882-83$.

143. Id. at 880, 897; see also Richard C. Levin, Appropriability, $R \& D$ Spending, and Technological Performance, 78 AM. ECON. REv. (PAPERS \& PROC.) 424, 427 (1988) (placing drug development in 
Merges and Nelson agree that small variations in chemical structure usually improve function only incrementally. But small changes also occasionally work radical shifts in clinical effect. ${ }^{144}$ These occasional departures from the discrete invention model may explain why courts seem to prefer narrow interpretations of pharmaceutical patent scope rather than broad findings of equivalents: construing patents narrowly and literally promotes a competitive market conducive to cumulative advances in technology. At the same time, the ease with which new chemical structure patents can be obtained for analogues of naturally occurring substances, as in our simvastatin example, is another consideration pointing in the same direction-away from the doctrine of equivalents as a practical way of protecting LDC rights in biodiversity pharmaceuticals.

\section{Rethinking Chemical Structure Patents}

The patent system as we have it today was really very little changed by the Patent Act of 1952; it goes back to a period when invention was largely mechanical, followed by an electrical era. In both, invention was chiefly of physical objects. The language and much of the judicial treatment of the statutes is geared to that sort of invention. When chemical invention became more frequent ... a problem arose of fitting chemical invention into a mold of words and a habit of thinking that were not developed with it in mind. ${ }^{145}$

The discussion to this point has shown the need for biodiversity patents to extend beyond mere chemical structure to their utility or clinical efficacy. Largely for reasons of clarity and convenience, American patents have until now attached solely to chemical structures. The supposed utility of a claimed chemical compound is only at issue when the patent is being reviewed. Once awarded, the right granted enjoins others from using the patented structure for any purpose, even a newly discovered one.

Though "chemical diagram" patent protection has been a historical fixture, the utility requirement for gaining a patent has not. Before the Court of Customs and Patent Appeals' (CCPA) decision in In re Bremner ${ }^{146}$ the U.S. Patent and Trademark Office (PTO) enforced no "specific utility" requirement. "[A] patent was granted almost automatically on a new chemical compound without any showing of utility."147 The present utility requirement was

discrete invention category, at least before "genetic revolution").

144. See supra text accompanying notes 85-86.

145. John Hoxie, A Patent Attorney's View, 47 J. PAT. OFF. Soc'y 630, 636 (1965).

146. 182 F.2d 216 (C.C.P.A. 1950) (denying patent application with no description of utility).

147. Eggert, supra note 116 , at 782 . 
developed in two 1967 CCPA decisions, In re Kirk ${ }^{148}$ and In re Joly, ${ }^{149}$ holding that chemical "tinker toys"- useful only in the furtherance of research when used as intermediates in synthesizing compounds with specific utilities-fail the basic utility test of the Patent Act. ${ }^{150}$ This position, which had been set forth by the Supreme Court one year earlier in Brenner $v$. Manson, ${ }^{151}$ did not deny the usefulness of these types of research tools but concluded that, as one commentator put it, "the potential reward in a basically untested chemical has become so enormous that ... a 17 year monopoly should not be granted until something more substantial is given in exchange than the disclosure that the compound exists." 152

This line of thinking complements the more venerable new-use doctrine, which precludes patents for newly discovered uses of a compound that either has already been patented or is an unpatentable product of nature. ${ }^{153}$ As In re Thuau states, the original patent holder for the compound is "entitled to every use of which his invention is susceptible."154 In Thuau, the applicant found that a patented leather tanning solution had a therapeutic medical value for treating cervicitis, but he received no rights from the Patent Office or the CCPA in exchange for his investigatory diligence. Later courts have sometimes deviated from the Thuau doctrine for new-use claims that are stated as process patents, ${ }^{155}$ allowing the first patentee broad and easily enforceable rights over the compound itself (i.e., its chemical structure) ${ }^{156}$ while giving the second, new-use patentee the right only to "preclude others from using the chemical in the exact manner he has disclosed. He acquires no right to produce the compound, to sell it, or even to use it." 157 The inequity of this system is

148. 376 F.2d 936 (C.C.P.A. 1967).

149. 376 F.2d 906 (C.C.P.A. 1967).

150. 35 U.S.C. § 101 (1988).

151. 383 U.S. 519, 534-35 (1966).

152. Eggert, supra note 116, at 773 (emphasis omitted).

153. No one has control over availability of the compound if it is a product of nature, otherwise known but never patented, or if the patent on it has expired. A new-use discoverer cannot in these cases assert the full chemical structure patent that an original discoverer could have. Id. at 780 n.67.

154. 135 F.2d 344, 347 (C.C.P.A. 1943).

155. This usage has been allowed since the 1952 Patent Act's modification of $\S 100(b)$ : "The term 'process' ... includes a new use of a known ... composition of matter, or material." Still, this provision is not thought to overrule Thuau in its entirety and to eliminate the "dominant" and "subservient" relationship, see infra note 157, of old-compound and new-use patents. See P.J. Federico, Commentary on the New Patent Act, 35 U.S.C.A. 1, 16-17 (West 1954), reprinted in 75 J. PAT. \& TRADEMARK OFF. SoC'Y 161 (1993); 1 CHISUM, supra note 106, \& 1.03[8]. In the words of a more recent Second Circuit opinion: Patents are not granted for the natural properties inherent in things existing in ... nature, although they may be granted for things an inventor does with those properties. . . A new use for an old material does not make the material patentable. But the new use or application of an old material may be patentable. Similarly, a process or method which involves only a new use of an old material is patentable.

Howes v. Great Lakes Press Corp., 679 F.2d 1023, 1029 (2d Cir.), cert. denied, 459 U.S. 1038 (1982).

156. Enforcement of the first inventor's patent may be carried out at the manufacturing level. Since the new-use patentee has rights that must be asserted at the user level, enforcement is more difficult. Eggert, supra note 116, at 781 .

157. Eggert, supra note 116, at 781. See also 4 CHISUM, supra note 106, § 16.02[4] ("One does not 
obvious. "The first inventor ... discloses one use, yet is 'paid' for all,"158 for she receives a patent in the chemical structure of the compound. This sort of arrangement might be equitable for patents on machines, which are tailored by their inventors to be ideal for one type of use, but biochemical inventions usually function by mechanisms dictated by nature and little understood by their discoverers. The patent system in these cases ought to encourage the search for uses per se, and not for useful compounds as it does now.

Despite its inequity as a system for compensating human efforts, ${ }^{159}$ something resembling a structure patent is exactly the sort of protection needed for biodiversity chemical structures. An LDC should be able to control the exploitation of its biodiversity resources regardless of the purpose for which they are used. Biodiversity patents should therefore be interpreted to subsume all routine manufacturing processes leading to the chemical structure, as well as use rights over the traditional medicinal use. ${ }^{160}$ At the same time, a drug company that uncovers a hitherto unknown use for an already patented, medicinally useful phytochemical could receive, in exchange for its investigatory effort, a patent on the specific use. It would then have the ability to contract exclusively with the LDC for the specific right to exploit that specific new use.

Replacing patents on chemical structures with patents for specific uses would not completely solve the Rio piracy problem, but it might help refocus infringement actions on utility. Under a Rio-inspired patent scheme, patents for uses and manufacturing processes would still refer to structures, but structure would not occupy the same central position in defining patent scope that it does now. Lay judges, notoriously unsure of themselves in patent cases, ${ }^{161}$ currently resolve equivalents controversies conservatively because they focus almost exclusively on the literal claim of the chemical structure diagram. Use

escape infringement by using a patented invention for a purpose not contemplated or disclosed by the patentee."). In these situations the first patent, on the chemical structure, is known as the dominant patent; the second, on the new use, is known as the subservient patent, or the blocking patent, since its holder may block the holder of the compound patent from using the compound for the newly discovered use. See Merges \& Nelson, supra note 109 , at $860-61$.

158. Eggert, supra note 116 , at 781 .

159. Considering biodiversity resources as natural resources, however, this mode of compensation for their use is neither inequitable nor inconsistent with values embodied in other laws dealing with rights to such resources. Again, this is because biodiversity patents serve the "prospect function" of patent grants, not the "reward function." See Kitch, supra note 136, at 271-75 (describing patent system as method of resource allocation analogous to mineral claims).

160. Ideally, a synthesis for the structure would be relatively easy to devise and execute. If not, the LDC could be given rights in the extraction process only. Vinblastine, for example, eludes a complete synthesis; the drug is still harvested-today from cell cultures of the rosy periwinkle, but until recently from the leaves of the plant itself. MYERS, supra note 7, at 200; see also id. at 92, 107. The private sector could compete to produce a workable synthesis, and, with its first-medical-use rights, the LDC would still be in a good position to extract a high share of the rents from any resulting marketed product.

161. See, e.g., Studiengesellschaft Kohle v. Eastman Kodak Co., 616 F.2d 1315, 1340 (5th Cir.), cert. denied, 449 U.S. 1014 (1980). 
patents would demand more subtle boundary-drawing between inventions because they would highlight distinctions in utility rather than structure. ${ }^{162}$

Of course, the scope of such "use" patents might be construed as narrowly as structure patents on pharmaceuticals are now. If the doctrine of equivalents does not develop sufficiently to cover look-alike piracy, a "distinct efficacy" requirement could be imposed on obtaining patents for new pharmaceuticals. Equivalents doctrine currently embodies a two-step test: newcomers are noninfringing either (1) if they possess a minimally distinct structure or (2) if, in the absence of a distinct structure, they demonstrate some unexpected utility-a distinct efficacy. The distinct efficacy test would require inventors to present more information in support of their claims for a new patent. This information would also elucidate the relationship between structural changes and efficacy changes. ${ }^{163}$ According to the prospect theory of patent scope, this relationship would determine whether broad or narrow patent scope should be allowed with respect to the use patent on the senior drug. If the relationship between small structural variations and function were predictable, the older patents would be construed broadly, since the original firm could be counted on to develop the product efficiently without market competition. But, if small changes did produce surprising variations in utility, then a narrow judicial construction of the patent would promote maximally efficient competition in these areas, with their relatively unlimited potentials for discovery. ${ }^{164}$

A distinct efficacy test might be implemented in a number of ways through the presently existing regulatory apparatus governing new pharmaceuticals. Most obviously, the PTO could require a patent applicant to demonstrate the distinct efficacy of its new pharmaceutical in order to satisfy the utility requirement of the Patent Act. ${ }^{165}$ Before the early 1960's, when Congress

162. Eggert, supra note 116 , at 788 .

163. All evaluations of patent scope benefit from being reviewed "in light of later technological developments." Merges \& Nelson, supra note 109, at 911 . Our current system resolves hard cases through the ex post vehicle of litigation, rather than demanding a more rigorous examination of the initial application, which is usually granted in doubtful cases.

164. Such a system raises concerns about the propriety of asking one party to provide expensive-toobtain data that might end up increasing the value of the opponent's property while producing no return for its originator. An administrative scheme to compensate the producer of data could be devised; such a scheme was upheld against constitutional challenge in Thomas v. Union Carbide Agric. Prods., 473 U.S. 568 (1985). Because producing the data needed to obtain regulatory approval is expensive, see supra note 92. the expropriation of such data is a prime concern of the pharmaceutical industry-almost as great a concern as patent expropriation. See, e.g., C.L. Clemente, A Pharmaceutical Industry Perspective, in INTELLECTUAL PROPERTY RIGHTS AND CAPITAL FORMATION IN THE NEXT DECADE, supra note 74, at 127, 127.

165. In Germany, a requirement that all patentable inventions display some "technical progress" over the prior state of the art was once part of the basic criteria of nonobviousness (called an "inventive step" in Europe). Wolfgang G. Fasse, Basic Patentability Requirements in the United States and Germany, 44 J. PAT. OFF. SOC'Y 27, 32-37 (1962); Frithjof E. Müller \& Harold C. Wegner, The 1976 German Patent Law, 59 J. PAT. OFF. SOC'Y 89, 116-17 (1977) (describing elimination of requirement). Note that Congress' power under the Patent Clause is granted in order to "promote the Progress of Science and the useful Arts," U.S. CoNST., art. 1, \& 8, cl. 8 (emphasis added); this phrasing suggests that patents should be granted only if the distinct efficacy of a claimed invention is demonstrated. 
expanded the FDA's regulatory powers over the pharmaceutical market, ${ }^{166}$ a showing of utility was a significant requirement for obtaining a patent on a new pharmaceutical. ${ }^{167}$ Since then, the utility requirement for patents on new pharmaceuticals has become substantially looser. ${ }^{168}$ The PTO's current Manual of Patent Examining Procedure states that patent applications shall be examined "recognizing that other agencies [e.g., the FDA] ... have been assigned the responsibility of assuring conformance to the standards established by statute for the advertisement, use, sale or distribution of drugs." ${ }^{\text {169 }}$ of course, Congress has the power to rearrange these responsibilities as it sees fit and to instruct the PTO to require a showing of distinct efficacy before granting a patent on a new pharmaceutical. Alternatively, a distinct efficacy test could be made a part of the safety regulations administered by the FDA. ${ }^{170}$ Unfortunately, while patent doctrines and the institutions that enforce them are similar across the globe, the national administrative systems that presently oversee the pharmaceutical industry vary greatly from country to country. As a result, regulatory solutions to problems of pharmaceutical patent scope may be difficult to implement in a uniform manner at the international level.

Any regime that eliminates structure patents or introduces a distinct efficacy test would increase the work of the patent office, the courts, or both. But within the field of laboratory chemical research, eliminating structure patents would "restore a balance between reward and contribution."171 And with respect to pharmaceuticals patterned on a protected natural structure, introducing a distinct efficacy test would force drug companies to decide whether they anticipate proving a new effect before they attempt to develop look-alike semi-synthetics. Thus, the distinct efficacy test would end the

166. See supra note 4 (describing Kefauver-Harris amendments).

167. See Isenstead v. Watson, 157 F. Supp. 7 (D.D.C. 1957) (stating that patent grant places government's moral imprimatur on product). Isenstead is cited as an example of a line of cases stretching back to the turn of the century in PAUL GOLDSTEN, COPYRIGHT, PATENT, TRADEMARK AND RELATED STATE DOCTRINES 425 (3d ed. rev. 1993).

168. See GolDSTEIN, supra note 167, at 425 . Compare In re Krimmel, 292 F.2d 948 (C.C.P.A. 1961) (holding that animal testing meets utility test by proving usefulness in treating animals) with In re Hartop, 311 F.2d 249, 257 (C.C.P.A. 1962) (holding that animal testing demonstrates "a sufficient probability of safety in human therapy ... to satisfy the requirement . . . that appellants' invention be useful"). Recall that the Kefauver-Harris amendments were enacted in 1962.

169. MANual of PATENT EXamining Procedure, supra note $107, \S 608.01(\mathrm{p})(\mathrm{A})(2)$.

170. This alternative approach could also be prudent from a safety perspective. The greater the number of structural variants a population uses to treat the same medical complaint, the higher the chance is of provoking some unforeseen side effect. Currently, breakthrough drugs tend to move through the regulatory system more rapidly than do follow-up drugs that clinically show only incremental improvements on the prior art. See Janet Aker, After the Storm: New Drugs Poised at FDA, MEDICAL MARKETING \& MEDIA, Jan. 1990, at 18, available in LEXIS, Nexis Library, MEDNET File (discussing slow progress of simvastatin through regulatory bureaucracy, as against lovastatin's rapid approval: The "FDA is not inclined to give follow-ups the same fast track as the breakthrough compound").

171. Eggert, supra note 116 , at 787. 
current wasteful, duplicative practice of pursuing variant structures merely for market positioning against competitors. ${ }^{172}$

\section{CONCLUSION}

When viewed abstractly, it is difficult to balance the long-term costs of losing biodiversity against the potential administrative and efficiency costs of a redistributive scheme that would allow LDC's to extract full economic rents from users of their biodiversity resources. Empirical research alone will not disclose the most efficient global approach to this problem, because the costs and benefits of any potential solution are dispersed over space and time and reflect incommensurate needs. Fortunately, this analysis of costs and benefits need not be undertaken in the abstract. The Rio Convention expresses the international determination that biodiversity resources are to be valued highly and that such resources should therefore be protected by patent rights. Having made this value determination, policymakers should also realize that it need not create unintended inefficiencies in the development of new pharmaceuticals, because a single rights holder, such as an LDC state with a Rio-inspired biodiversity patent, will be able to orchestrate further development just as efficiently as the market can. ${ }^{173}$

Like the more familiar heuristic, hit-or-miss synthetic research, phytochemical prospecting tends to produce breakthrough drugs, discrete leaps forward in the state of the art. For both normative and economic reasons, these types of advances demand broad protective scope, and in other areas they often receive it. Unfortunately, existing patent doctrines usually give look-alike pharmaceuticals the benefit of the doubt. Obviousness, an ex ante concept, offers little protection to the scope of Rio-inspired biodiversity patents, especially in light of the judicial interpretation of this doctrine in the United States. The doctrine of equivalents is more promising, because it involves an ex post reexamination of the initial patent in the light of developments occurring between the first grant and the copying. However, the practical usefulness of the doctrine of equivalents is undermined by judicial reliance on subjective evaluations of "structural similarity," from which equivalent biochemical mechanisms are then inferred. ${ }^{174}$ Decisionmakers could strengthen this doctrine by focusing first on the issue of utility or efficacy, rather than relying on structure to establish a prima facie case of equivalents.

172. See supra text accompanying notes $85-103$.

173. This seems even more likely in light of the tendency of drug companies to invest in marketing-usually of market-redundant goods-at a magnitude resembling that of their research budgets. See supra note 89 and accompanying text. The basic scientific research establishment has recently been criticized for generating extensive redundancy. See Grand Unified Experiments, ECONOMIST (U.S. Edition), May 1, 1993, at 18.

174. See, e.g., supra notes 125 \& 127. 
The proposals made here would help the courts and patent office afford pharmaceutical biodiversity resources the broad protective scope they need.

We must assume that most pharmaceutical biodiversity resources would be developed regardless of the scope of Rio patents. But approaching this issue without considering how LDC's might extract the maximum economic rents from their biological diversity ignores the sizeable global efficiencies and the welfare benefits for Third World nations that would result from the full redistribution of these rents from North to South. Impoverished nations will be more likely to conserve their biodiversity resources if conservation pays for itself, and, from a global standpoint, conservation is a good long-term investment. Perhaps more significantly, economic redistribution from North to South could have a tremendous impact on the pharmaceutical industry in the Third World, helping not only to preserve the biodiversity resources of poorer nations, but also to finance badly needed indigenous pharmaceutical companies. Such companies can address the Third World's need for drugs that transnational corporations find unprofitable to develop. ${ }^{175}$ Ironically, even today many of the citizens of these nations have no choice but to rely on plants and herbs as their primary pharmaceutical sources. ${ }^{176}$

175. The public health needs of the underdeveloped world are primarily pediatric, whereas those in the developed world are primarily geriatric. Carl Djerassi, Making Drugs (and Soaking the Poor?), 310 NATURE 517 (1984). Agenda 21's elaboration on the terms of the Rio Convention endorses strengthening the "endogenous capacities" of LDC's to develop self-sufficiency in the application of biotechnology. It also proposes extending the usually short patent terms in LDC's, which would benefit transnational pharmaceutical companies by expanding the patent protection available for their high-end products in the Third World; in exchange, the big pharmaceutical companies are supposed to increase their research on the health concerns of LDC populations. 2 AGENDA 21 \& THE UNCED PROCEEDINGS, supra note 19, at 671, 674.

176. "Of the five billion people in the world, four billion depend to some extent on traditional, or 'folk,' remedies. Thanks to fashion and the rising cost of finding new drugs, the other billion are on their way to following them." Medicinal Plants: Pills in a Haystack, ECONOMIST (U.S. Edition), Feb. 24, 1990, at 87; see also Norman Famsworth, Screening Plants for New Medicines, in BIODIVERSITY, supra note 9, at 83,91 . 